\title{
SEDIMENT EXPORT DYNAMICS REFLECTING THE HOLOCENE HYDRODYNAMIC VARIABILITY OF A HIGH-ENERGY CONTINENTAL SHELF SYSTEM (SOUTHEASTERN SOUTH AMERICA)
}

\section{Till JENS JöRg HANEBUTH ${ }^{1, *}$, , Vera Barbara BENDER ${ }^{2}$ AND RENATA HANAE NAGAI ${ }^{3}$}

1 Coastal Carolina University, Department of Coastal and Marine Systems Science, Conway, South Carolina 29526, U.S.A. 2 University of Bremen, MARUM - Center for Marine Environmental Sciences, Leobener Strasse, 28359 Bremen, Germany 3 Universidade Federal do Paraná, Centro de Estudos do Mar, Curitiba, Paraná, Brazil

* Corresponding AUTHor, thanebuth@coastal.de

Received on 30 July 2019

Received in revised form on 28 September 2019

Accepted on 28 September 2019

Editor: Maria Virginia Alves Martins, Universidade do Estado do Rio de Janeiro

\section{Citation:}

Hanebuth, T.J.J., Bender, V.B., Nagai, R.H., 2019. Sediment export dynamics reflecting the Holocene hydrodynamic variability of a highenergy continental shelf system (Southeastern South America). Journal of Sedimentary Environments, 4 (3): 312-331.

\section{Abstract}

This study reconstructs Holocene hydrodynamic changes on the outer shelf off Uruguay by examining deposits from a morphological terrace on the uppermost continental slope $(250 \mathrm{~m}$ water depth). Seismo-acoustics, litho- and chronostratigraphy, granulometry, and Neodymium isotopy were applied to three sediment cores. The 9.5-m thick terrace sediment record, documenting the past $11.5 \mathrm{cal} \mathrm{ka}$ $\mathrm{BP}$, provides exceptional insight into the transport and settling mechanisms of the sand injected from the shelf into the open ocean. The sandy outer shelf is identified as the principal sediment origin. Contouritic bottom currents do not significantly affect deposition on the terrace. Instead, the sandy sediment gets spilled over the shelf edge in the form of suspension clouds, spreading uniformly over the whole terrace. The suspended sand does not transform into highconcentration gravity-driven bottom flows but rains down onto the terrace as a quasi-permanent material supply. This observation suggests that the formation of turbidite beds, as frequently found at the deeper slope in this region, requires first a temporary storage of sediment at deposition-favoring

\section{Introduction}

The relevance of getting insight into past export dynamics of sand over the edge of a continental shelf is twofold. On the one side, the history of sediment mobilization on the outer shelf is driven by the variability of the oceanographic conditions as part of the regional climatic system. On the other hand, understanding the principle physical mechanism, which leads to significant supply of sand into the deep ocean, might be of economical relevance as a modern analogue to the origin of deep-sea sandstone reservoirs. locations on the uppermost continental slope (terraces, canyon heads), before a secondary and episodic process can mobilize the mass.

An overall fining-upward trend in silty sand shelf export over Holocene times reflects the deglacial sea-level rise dynamics, leading to overall less effective material mobilization on and transfer across the shelf due to water deepening. The pronounced vertical hydrographic shelf front, as a shallow expression of the regional oceanic confluence zone, acted temporarily as main sediment exporting conveyer, before it shifted further north. The water depth of the terrace coincides with the transition zone between Central Water and Intermediate Water. The pronounced water density gradient might influence sediment distribution twofold, acting as a barrier for sand suspension cloud spreading as well as a medium for incoming internal waves bringing sediment remobilization.

Keywords: Shelf sediment export. High-energy ocean margin. Southeast South America. Holocene.

Though continental shelves commonly host coarsegrained sediment at their outer edge (e.g., Swift, 1974), understanding the mechanisms and history of sand export is commonly hindered by the lag of a suitable depositional record. The outer-shelf hydrodynamic regime is usually too variable to allow for continuous accumulation of material. The sandy lower-slope records are often overprinted by efficient secondary sediment sorting (i.e., current-driven contour-parallel or gravity-driven downslope transport processes; e.g., Reading and Richards, 1994; Stow et al., 2002). The uppermost continental slope, though a prime 
place for directly documenting shelf sediment export, is generally too steep to reliably archive sedimentation. As a consequence, a gap in knowledge exists with regard to outershelf sediment mobilization processes, though this transport may ultimately lead to significant material loss from the shelf system.

This study presents data from an exceptional uppermostslope terrace at $220-340 \mathrm{~m}$ modern water depth off Uruguay. This terrace carries a 15-m thick depositional succession and has acted as an instantaneous trap for shelfderived material during and prior to Holocene times. The dominant sedimentary processes (outer-shelf hydrodynamic effects, cross-shelf export mechanisms, bottom-current transport) leading to the buildup of these strata are discussed based on seismo-acoustic profiles, lithological texture, grainsize distribution, and terrigenous Neodymium isotopic data.

\section{Study Area}

The western South Atlantic margin is dominated by the encounter of the poleward-flowing Brazil Current (BC) and the equatorward-flowing Malvinas Current (MC), forming the Brazil-Malvinas Confluence (BMC) at intermediate water depths (500-1000 m; Peterson and Stramma, 1991; Stramma and England, 1999). Along the upper slope, BC transports the superficial Tropical Water (TW) and underlying South Atlantic Central Water (SACW) in southward direction, whilst MC moves the near-surface Sub-Antarctic Water (SAW) and the underlying upper part of the Antarctic Intermediate Water (AAIW) to the north (for references see Franco-Fraguas et al., 2014).

On the continental shelf, this pattern is pursued by the coalescence of the Sub-Antarctic Shelf Water (SASW) and the Sub-Tropical Shelf Water (STSW), jointly forming the Sub-Tropical Shelf Front (STSF; Fig. 1a; Piola et al., 2000, 2008). The density-compensated thermohaline structure of the STSF favors an efficient offshore advection of these two colliding water masses. This structure makes the STSF both a latitudinal hydrographic barrier as well as a critical component for cross-shelf water circulation and sediment transport (Piola et al., 2008; Matano et al., 2010).

The hydrographic regime on the inner shelf is strongly influenced by the Plata Plume Water (PPW), resulting from the tremendous Río de la Plata river discharge $\left(23,000 \mathrm{~m}^{3} / \mathrm{s}\right)$, and to a minor degree from the Patos Lagoon outflow $\left(1,750 \mathrm{~m}^{3} / \mathrm{s}\right.$ ) (Piola et al., 2000, 2008; Isupova and Mikhailov, 2018). As a distinct low-salinity buoyant plume, PPW is, on long-term average, directed northeast-ward parallel to the coast, and its maximum extension is determined by the regional alongshore wind stress (Piola et al., 2005; Möller et al., 2008).

According to the Ocean Circulation and Climate Advanced Modeling (OCCAM) project, SASW and STSW are transported over the outer shelf with velocities of up to
RESEARCH PAPER

30 and $20 \mathrm{~cm} / \mathrm{s}$, respectively (Gwilliam, 1996). Thus, the bottom currents transporting the two shelf water masses have a great potential to transport fine-sandy sediment (e.g., Miller et al., 1977).

Clay-mineralogical analyses between $40^{\circ} \mathrm{S}$ and $27^{\circ} \mathrm{S}$ have suggested that the STSF acts as an effective boundary separating sandy sediment to the South from silty/clayey sediment contributed by the Río de la Plata river and the Patos Lagoon (Campos et al., 2008). Consequently, the modern Southeastern South America (SESA) shelf south of $35^{\circ} \mathrm{S}$ is widely covered by siliciclastic sand and bioclastic gravel, whereas a silt to silty clay tongue extends further north on the inner to middle shelf (Martins et al., 2003; Violante et al., 2010; Lantzsch et al., 2014).

Neodymium isotopic $(\varepsilon \mathrm{Nd})$ data in the range of -4 to 0 showed that the siliciclastic sands south of $35^{\circ} \mathrm{S}$ originate from a continental province in Patagonia (younger Andean volcanic rocks), in contrast to the more negative $\varepsilon \mathrm{Nd}$ signature of -8 to -11 found in the terrigenous deposits further north (sourced from tholeitic basalts and Paleozoic rocks in the Río de la Plata drainage basin; Mahiques et al., 2008; Mantovanelli et al., 2018).

The outer shelf off Uruguay shows a relict landscape with terraces and depressions, which had probably formed during the Last Glacial Maximum shelf exposure (Martins et al., 2005; Parker et al., 2005). This old surface topography is partly covered by fine sand from transgressive and modern times (Lantzsch et al., 2014).

In line with the general geomorphology off SESA, the upper continental slope off Uruguay is steep (Urien and Ewing, 1974) and hosts a series of shelf-cutting gullies and channels (Franco-Fraguas et al., 2014). The contour-parallel bottom currents, that have dominate the regional and local sediment transport and depositional pattern at the continental slope off northern Argentina and Uruguay over Late Paleogene and Neogene, have formed a huge contouritic terrace-channel succession (Hernández-Molina et al., 2009; 2016; Preu et al., 2012).

The terrace in the focus of this study represents the shallowest of these contouritic terraces. It discontinuously extends from northern Argentina to the Campos Basin off southeastern Brazil (Viana and Faugéres, 1998; HernándezMolina et al., 2016). The terrace section in the study area is latitudinally bounded by two major canyons to its north and south (Franco-Fraguas et al., 2014; the Piriápolis and José Ignacio canyon systems: Hernández-Molina et al., 2016).

\section{Material and methods}

During R/V METEOR cruise M78/3a off Uruguay in 2009 (Krastel et al., 2012; Fig. 1, Tab. 1), sub-bottom seismoacoustic imaging was performed with the shipboard sediment echosounder system (PARASOUND P70), using the secondary $4 \mathrm{kHz}$ signal derived from the parametric effect (Figs. 2, 3). 
Tab. 1. Coring sites. GC-12: gravity-corer equipped with a 12-m core barrel. VC-5: vibro-corer equipped with a 5-m core barrel.

\begin{tabular}{|c|c|c|c|c|c|c|}
\hline $\begin{array}{c}\text { Core } \\
(\mathbf{G e o B}-)\end{array}$ & $\begin{array}{c}\text { Coring } \\
\text { device }\end{array}$ & Latitude & Longitude & $\begin{array}{c}\text { Water } \\
\text { depth }(\mathbf{m})\end{array}$ & \multicolumn{1}{|c|}{$\begin{array}{c}\text { Location } \\
(\mathbf{c m})\end{array}$} \\
\hline $\mathbf{1 3 8 0 1 - 2}$ & GC-12 & $36^{\circ} 08.49^{\prime} \mathrm{S}$ & $53^{\circ} 17.96^{\prime} \mathrm{W}$ & 241 & Uppermost slope & 955 \\
\hline $\mathbf{1 3 8 4 0 - 1}$ & GC-12 & $35^{\circ} 49.21^{\prime} \mathrm{S}$ & $52^{\circ} 54.56^{\prime} \mathrm{W}$ & 232 & Uppermost slope & 387 \\
\hline $\mathbf{1 3 8 4 1 - 2}$ & GC-12 & $35^{\circ} 49.53^{\prime} \mathrm{S}$ & $52^{\circ} 53.87^{\prime} \mathrm{W}$ & 285 & Uppermost slope & 817 \\
\hline $\mathbf{1 3 8 3 5 - 2}$ & VC-5 & $35^{\circ} 43.10^{\prime} \mathrm{S}$ & $53^{\circ} 05.13^{\prime} \mathrm{W}$ & 131 & Outermost shelf & 506 \\
\hline $\mathbf{1 3 8 3 6 - 2}$ & VC-5 & $35^{\circ} 44.72^{\prime} \mathrm{S}$ & $53^{\circ} 03.66^{\prime} \mathrm{W}$ & 135 & Outermost shelf & 507 \\
\hline $\mathbf{1 3 8 3 7 - 2}$ & VC-5 & $35^{\circ} 46.18^{\prime} \mathrm{S}$ & $53^{\circ} 02.29^{\prime} \mathrm{W}$ & 140 & Outermost shelf & 314 \\
\hline
\end{tabular}

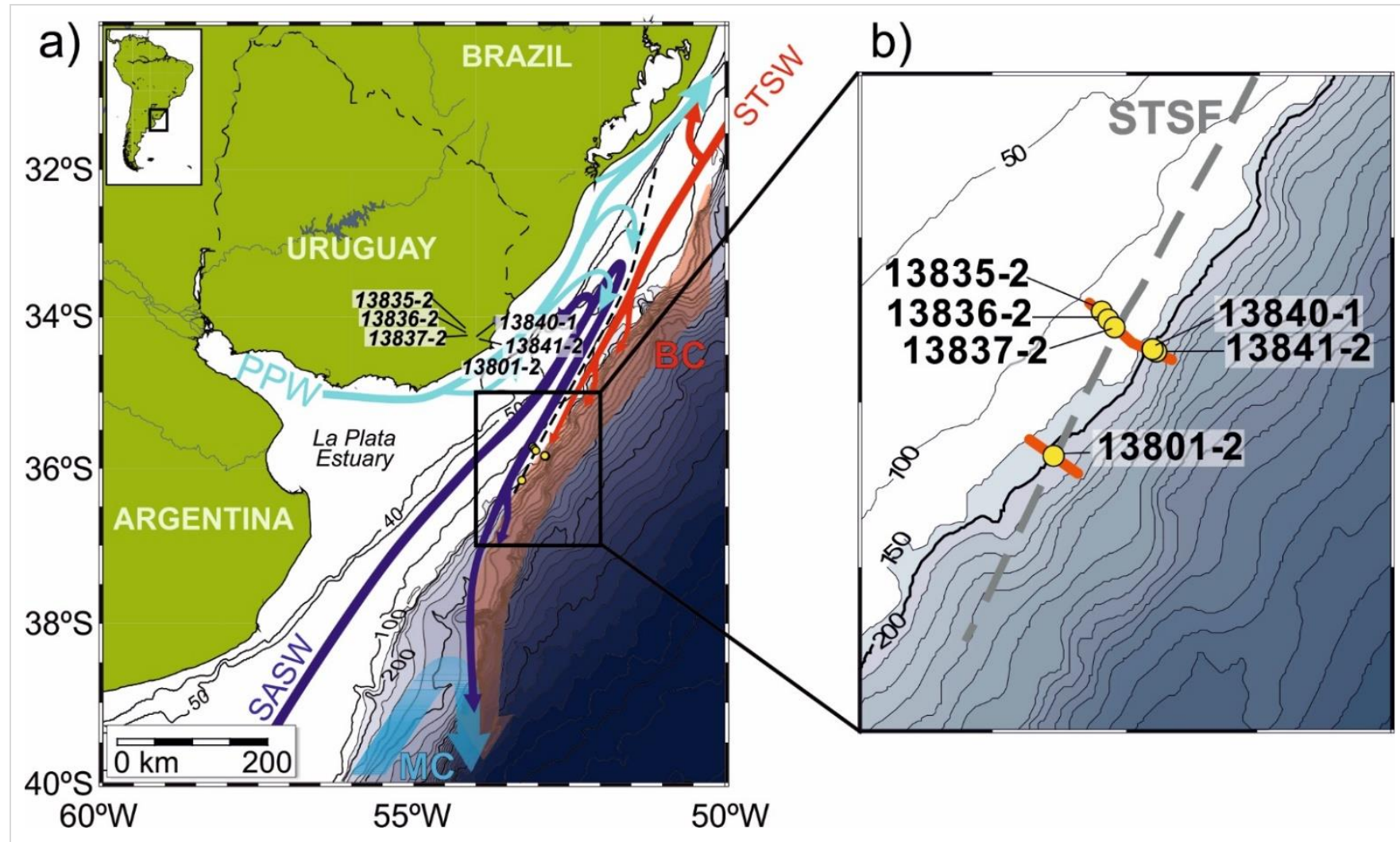

Fig. 1. Study area at the Southeast South American continental margin. (a) Oceanographic features representing the mean winter circulation patterns (after Piola et al., 2008); BC: Brazil Current; MC: Malvinas Current; PPW: Plata Plume Water; SASW: Sub-Antarctic Shelf Water; STSW: Sub-Tropical Shelf Water). (b) Close-up on the location of studied GeoB cores (yellow dots) and PARASOUND profiles (red lines) across the shelf edge.

Three sediment gravity cores were obtained from the uppermost-slope terrace (GeoB13801-2, GeoB13840-1, GeoB13841-2; Figs. 2, 3). In addition, three vibracores from the outer shelf were included reflecting the local potential sediment source (GeoB13835-2, GeoB13836-2, GeoB13837-2; Fig. 2; (Lantzsch et al., 2014).

The age determination of the three terrace cores is based on 16 accelerator mass spectrometer radiocarbon (AMS- ${ }^{14} \mathrm{C}$ ) dates, measured at the Poznan Radiocarbon Laboratory (Poland) on well-preserved benthic foraminifera test or bivalve shells, hand-picked from the $>250 \mu \mathrm{m}$ fraction (Tab. 2). Dates were converted into $1 \sigma$ calibrated ages using Calib 6.1.1 by using the standard marine reservoir effect of 405 years (Reimer et al., 2009). A continuous depth-age model was calculated for core GeoB13801-2 using the Bayesian approach accumulation model "Bacon" (Blaauw and Christen, 2011) and a simple age-depth linear interpolation was done for core GeoB134841-2 (Fig. 4). In the following, all ages are given in calibrated thousands of years before present (cal ka BP). 
Tab. 2. Radiocarbon age data.

\begin{tabular}{|c|c|c|c|c|c|}
\hline $\begin{array}{l}\text { Core / } \\
\text { Lab code }\end{array}$ & $\begin{array}{c}\text { Sample } \\
\text { depth }(\mathrm{cm})\end{array}$ & Material & $\begin{array}{l}\text { Raw }{ }^{14} \mathrm{C} \\
\text { age } \\
\text { (yrs BP) }\end{array}$ & $\begin{array}{l}1 \sigma \text { calibrated } \\
\text { age range } \\
(\text { cal a BP) }\end{array}$ & $\begin{array}{c}\text { Calibrated age } \\
\text { intercept } \\
\text { (cal ka BP) } \\
\end{array}$ \\
\hline \multicolumn{6}{|l|}{ GeoB13801-2 } \\
\hline Poz-42421 & 20 & $\begin{array}{l}\text { Mixed, well-preserved benthic } \\
\text { foraminifera; sized } 250-1000 \mu \mathrm{m}\end{array}$ & $800 \pm 30$ & $420-479$ & $0.45 \pm 0.03$ \\
\hline Poz-42425 & 50 & $\begin{array}{l}\text { Mixed, well-preserved benthic } \\
\text { foraminifera, sized } 250-1000 \mu \mathrm{m}\end{array}$ & $1,155 \pm 30$ & $665-723$ & $0.69 \pm 0.03$ \\
\hline Poz-42422 & 209 & Uvigerina bifurcata, 250-500 $\mu \mathrm{m}$ & $3,730 \pm 50$ & $3,572-3,720$ & $3.65 \pm 0.07$ \\
\hline Poz-42423 & 375 & $\begin{array}{l}\text { Mixed, well-preserved benthic } \\
\text { foraminifera and unbroken } \\
\text { echinoderm } \\
\text { spines; sized } 250-1000 \mu \mathrm{m}\end{array}$ & $5,890 \pm 40$ & $6,265-6,353$ & $6.31 \pm 0.04$ \\
\hline Poz-42424 & 404 & $\begin{array}{l}\text { Mixed, well-preserved benthic } \\
\text { foraminifera and unbroken } \\
\text { echinoderm spines; } \\
\text { sized } 250-1000 \mu \mathrm{m}\end{array}$ & $6,535 \pm 35$ & $6,998-7,118$ & $7.06 \pm 0.06$ \\
\hline Poz-35195 & 540 & Uvigerina bifurcata, 250-500 $\mu \mathrm{m}$ & $8,180 \pm 40$ & $8,589-8,733$ & $8.66 \pm 0.07$ \\
\hline Poz-42426 & 686 & Uvigerina bifurcata, 250-500 $\mu \mathrm{m}$ & $8,970 \pm 50$ & $9,539-9,688$ & $9.61 \pm 0.07$ \\
\hline Poz-42427 & 750 & $\begin{array}{l}\text { Mixed, well-preserved benthic } \\
\text { foraminifera; sized } 125-1000 \mu \mathrm{m}\end{array}$ & $9,130 \pm 60$ & $9,771-10,032$ & $9.90 \pm 0.13$ \\
\hline Poz-35197 & 945 & $\begin{array}{l}\text { Fresh (periostracum preserved) } \\
\text { bivalves } \\
\text { of Yoldiella genus, } 1000 \sim 3000 \mu \mathrm{m}\end{array}$ & $9,560 \pm 50$ & $10,366-10,503$ & $10.43 \pm 0.07$ \\
\hline
\end{tabular}

\section{GeoB13840-1}

$\begin{array}{lccccc}\text { Poz-36078 } & 313 & \text { Uvigerina bifurcata, 250-500 } \mu \mathrm{m} & 7,880 \pm 40 & 8,312-8,386 & 8.35 \pm 0.04 \\ \text { Poz-36079 } & 384 & \text { Uvigerina bifurcata, 250-500 } \mu \mathrm{m} & 8,660 \pm 50 & 9,279-9,406 & 9.34 \pm 0.06\end{array}$

\section{GeoB13841-2}

\begin{tabular}{|c|c|c|c|c|c|}
\hline Poz-42435 & $34-35.5$ & Globobulimina spp., 250-500 $\mu \mathrm{m}$ & $2,170 \pm 30$ & $1,750-1,810$ & $1.78 \pm 0.03$ \\
\hline Poz-36080 & 183-188 & $\begin{array}{l}\text { Fresh (periostracum preserved) } \\
\text { bivalves } \\
\text { of Yoldiella genus, } 1000 \sim 3000 \mu \mathrm{m}\end{array}$ & $9,190 \pm 50$ & $9,920-10,106$ & $10.01 \pm 0.09$ \\
\hline Poz-36081 & 400 & $\begin{array}{l}\text { Fresh (periostracum preserved) } \\
\text { bivalves } \\
\text { of Yoldiella genus, } 1000 \sim 3000 \mu \mathrm{m}\end{array}$ & $9,690 \pm 50$ & $10,505-10,588$ & $10.55 \pm 0.04$ \\
\hline Poz-36082 & 545-547 & $\begin{array}{l}\text { Fresh (periostracum preserved) } \\
\text { bivalves } \\
\text { of Yoldiella genus, } 1000 \sim 3000 \mu \mathrm{m}\end{array}$ & $9,960 \pm 50$ & 10,812-11,065 & $10.94 \pm 0.13$ \\
\hline Poz-36084 & 782 & $\begin{array}{l}\text { Fresh (periostracum preserved) } \\
\text { bivalves } \\
\text { of Yoldiella genus, } 1000 \sim 3000 \mu \mathrm{m}\end{array}$ & $10,430 \pm 50$ & $11,361-11,637$ & $11.50 \pm 0.14$ \\
\hline
\end{tabular}


The lithology of the three terrace cores were primarily based on a detailed visual core description. The textural classification after Folk (1968) aided the lithological identification. For the identification and visualization of internal structures (e.g., bioturbation, lamination), cores GeoB13801-2 and GeoB13841-2 were X-ray imaged after having prepared continuous $7-\mathrm{mm}$ thick slab samples.

The terrace cores GeoB13801-2 and GeoB13841-2 were sampled for grain-size analysis at $10 \mathrm{~cm}$ and $20 \mathrm{~cm}$ intervals, respectively. In addition, a set of 12 samples was taken from the three outer-shelf cores. Grain size was analyzed in the
RESEARCH PAPER range 0.4-2000 $\mu \mathrm{m}$ with a Coulter Laser Particle Sizer LS200. For each sample set, one series of aliquots ("bulk") was analyzed chemically untreated and the material of a second series ("terrigenous") was digested in successive steps with $35 \% \mathrm{H}_{2} \mathrm{O}_{2}, 10 \% \mathrm{HCl}$, and $6 \% \mathrm{NaOH}$ to remove organic carbon, biogenic carbonate and opal, respectively.

Selected samples of core GeoB13801-2 were analyzed for their Neodymium (Nd) isotopic composition at the Geochronological Research Center of the University of São Paulo.

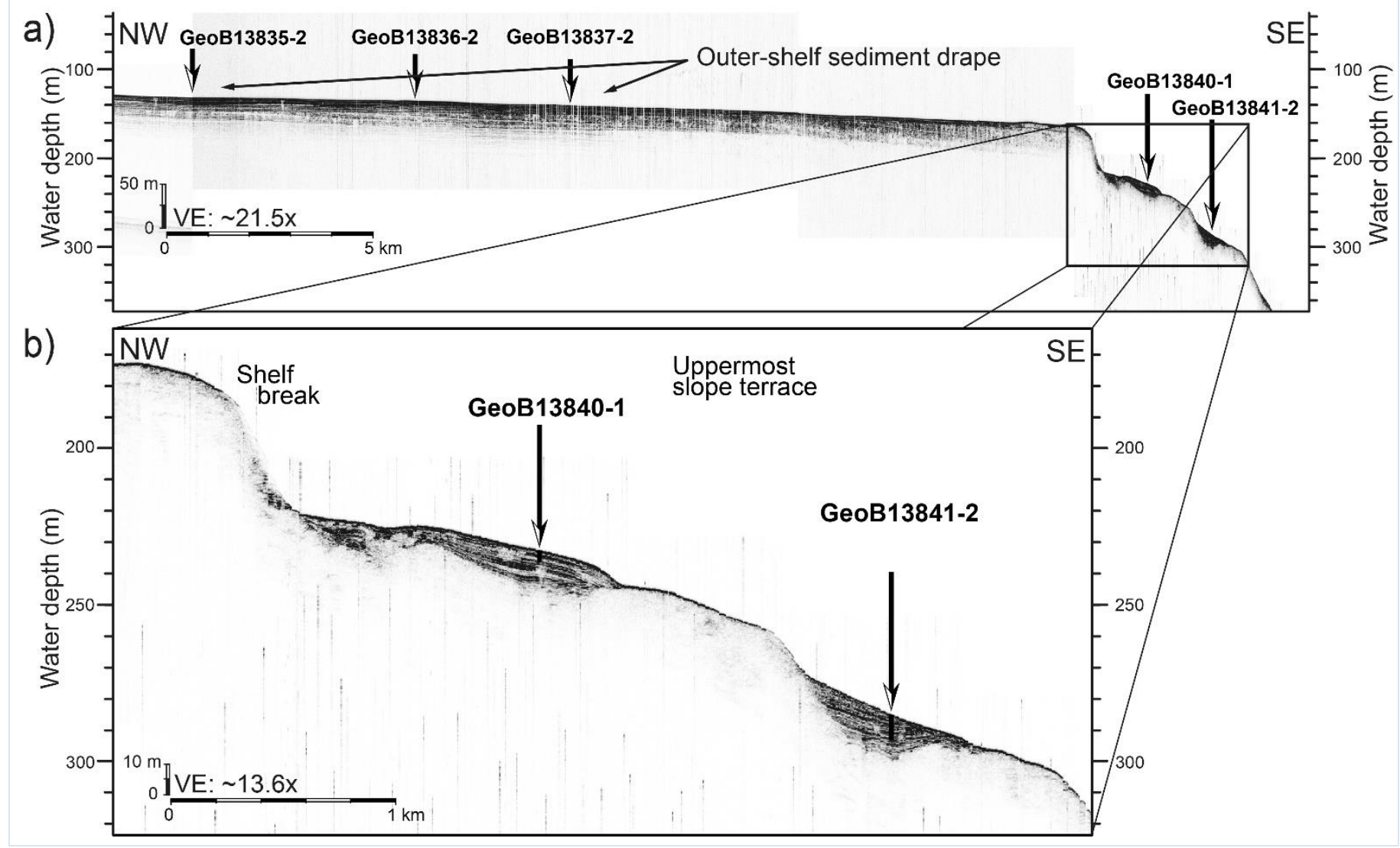

Fig. 2. (a) PARASOUND profile line crossing the locations of sediment cores GeoB13835-2; GeoB13836-2; GeoB13837-2 on the outer shelf and GeoB13840-1 and GeoB13841-2 on the uppermost slope terrace (cf. Fig. 1b). (b) Blow-up of the profile section covering the uppermost slope terrace. Note the separation of a shelf proximal and shelf distal depocenter by an acoustic basement high. Vertical black bars indicate the approximate core penetration depth.

For comparability, sample preparation and the analytical procedure followed the description given by Mahiques et al. (2008) based on Sato et al. (1995). Analyses were performed with a multicollector Finnigan MAT262 mass spectrometer. $\mathrm{Nd}$ ratios were normalized to a ${ }^{143} \mathrm{Nd} /{ }^{144} \mathrm{Nd}$ ratio of 0.7219 (Hamilton et al., 1983).

\section{Results}

The outer shelf at $35^{\circ} 50^{\prime} \mathrm{S}$ is covered by a thin $(<5 \mathrm{~m})$ sediment drape of homogenous fine sands, which are recovered by cores GeoB13835-2, GeoB13836-2 and
GeoB13837-2. The shelf break occurs at a water depth of $180 \mathrm{~m}$ (Fig. 2). Below a steep upper-slope step with a slope gradient of $9^{\circ}$, a $3.5-\mathrm{km}$ wide terrace extends between 220 and $300 \mathrm{~m}$ water depth with an average gradient of $1.5^{\circ}$ (Terrace TO in analogy with the terminology used by Hernández-Molina et al., 2009 and Preu et al., 2012). The slope significantly steepens again to $6^{\circ}$ below this terrace.

Two local sedimentary depocenters are developed on the terrace, separated by an acoustic basement high (Fig. 2b). The upper (inner, shelf-proximal) depocenter at 220 to $245 \mathrm{~m}$ water depth is $12 \mathrm{~m}$ thick in its center and shows a 
convex, mounded surface geometry. Towards its seaward limit, the stratified acoustic facies of this depocenter is
RESEARCH PAPER punctually blanked out, which might hint to subordinate sediment creeping (Fig. 2b).

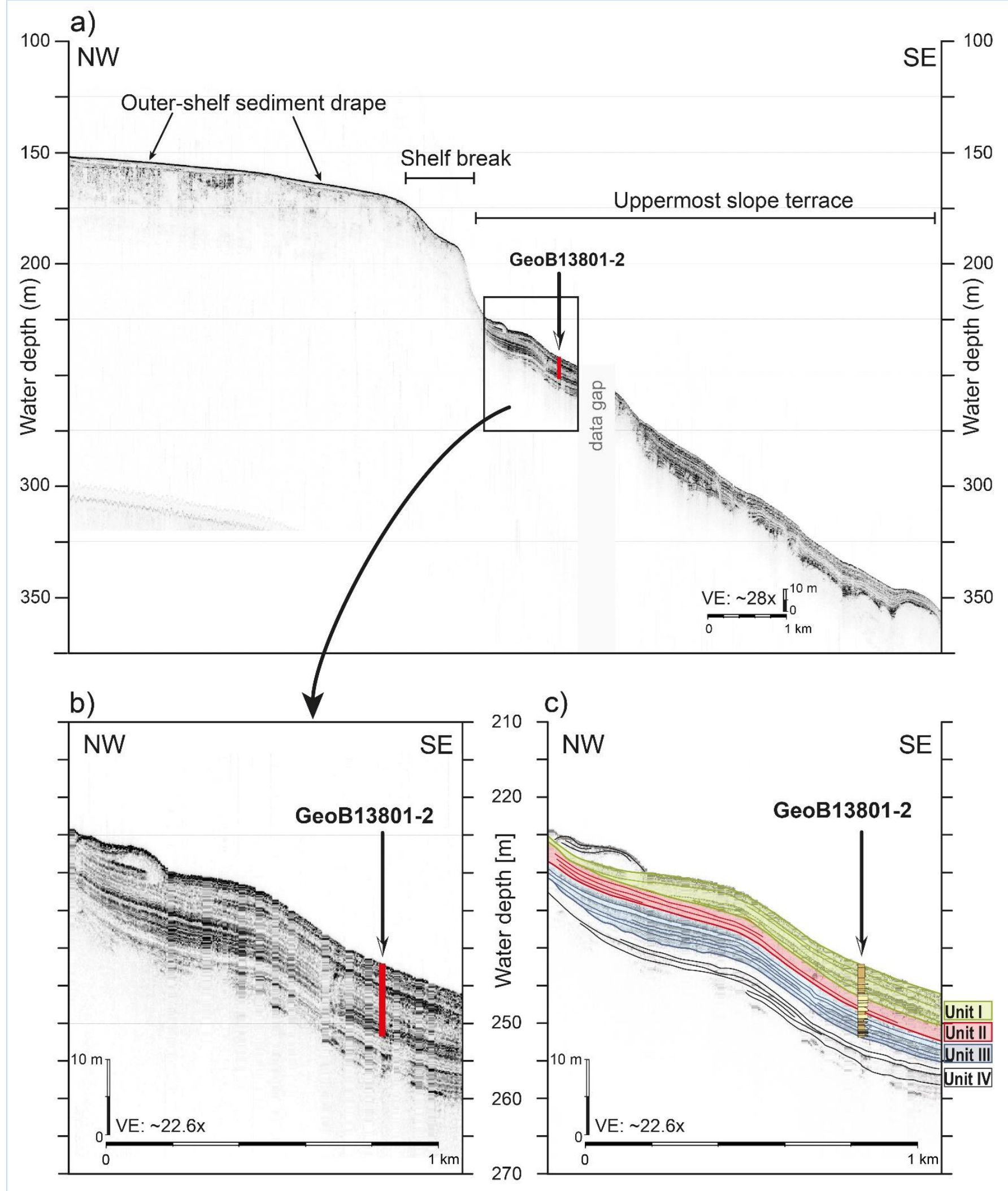

Fig. 3. (a) PARASOUND profile line from the outer shelf down to the outer margin of the uppermost slope terrace, crossing the location of sediment core GeoB13801-2 (cf. Fig. 1b). (b and c) original and interpreted (PARASOUND units I - IV indicated to the right of panel c) blow-up of the profile section across the core location. Note the generally undisturbed stratification at the core location. Vertical black bars in (a) and (b) indicate approximate core penetration depth. 


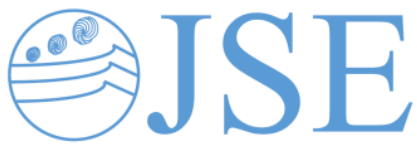

RESEARCH PAPER

The internal stratification indicates subtle progradational growth into seaward direction. Gravity core GeoB13840-1 was obtained from this upper depocenter and is covering the uppermost $387 \mathrm{~cm}$. Between the shelf edge and this depocenter, a 500-m wide paleo-depression is filled with a stratified deposit (Fig. 2b). This trough-like structure might represent a refilled, i.e. abandon contouritic moat. The fill is covered by a younger transparent sheet-like deposit, which probably represents a gravity-driven debritic collapse deposit.

The lower (outer, shelf-distal) depocenter between 270 and $300 \mathrm{~m}$ water depth is up to $15 \mathrm{~m}$ thick (Fig. 2b). It appears not mounted as the upper depocenter but levels out an acoustic basement depression towards the terrace edge. This lower depocenter is also internally stratified and climbing reflectors indicate an upward growing formation history (in contrast to the upper depocenter), probably related to a temporary slope bottom current that has prevented sediment to deposit at the steeper flank. Gravity core GeoB13841-2 recovered the upper $817 \mathrm{~cm}$ of this depocenter, which allows for a comparison of proximal and distal sedimentation dynamics across the terrace.

$50 \mathrm{~km}$ to the south at $36^{\circ} 08^{\prime} \mathrm{S}$, the outer shelf is covered by a laterally not fully continuous, up to 3-m thick sediment drape (Fig. 3; Lantzsch et al., 2014). The shelf break occurs with two steps at 175 and $195 \mathrm{~m}$ water depth, and the uppermost-slope gradient steepens to $7^{\circ}$ (Fig. 3). Between 225 and $350 \mathrm{~m}$ water depth, the slope gradient is reduced to $1.3^{\circ}$ forming Terrace TO. Here, TO is $5.5 \mathrm{~km}$ wide and covered by up to $15 \mathrm{~m}$ of sediment (Fig. 3a). The succession shows stratified acoustic facies, which drapes the underlying wavy acoustic basement. The stratification follows a parallel pattern, hinting to quasi-vertical sediment deposition. Local thinning of this drape over elevated humps in the basement indicates that some sediment condensation took place at these exposed locations, claiming for a certain control of bottom currents over vertical sediment settling. As it was at the further northward located site, gravity-driven sediment slumping in the innermost area of this depocenter is evidenced by locally restricted transparent seismo-acoustic layers. Gravity core GeoB13801-2 was taken from this depocenter with a recovery of $955 \mathrm{~cm}$; following the intention to document the undisturbed deposition dynamics as close to the shelf edge as possible.

From the radiocarbon-based age framework and detailed visual core description it emerges that core GeoB13801-2 is the only of the three terrace cores with a continuous sedimentary succession (Fig. 4). Consequently, this core was used as the reference record for the litho- and chronostratigraphic correlation with the other two terrace cores. For core GeoB13841-2, five radiocarbon dates (Tab. 2) and one age tie point (encircled in Fig. 4a) obtained from the litho- and chronostratigraphic correlation (Fig. 5) exist. The oldest terrace sediment was recovered by core GeoB13841-2, dating back to 11.5 cal ka BP (Figs. 4 and 5; Tab. 2). Both cores, GeoB13801-2 and GeoB13841-2, show linear sedimentation rates (LSR) of up to $400 \mathrm{~cm} / \mathrm{kyr}$ prior to $10 \mathrm{cal} \mathrm{ka} \mathrm{BP}$ (Fig. 4b). Whereas the time interval 10.0$4.5 \mathrm{cal} \mathrm{ka} \mathrm{BP}$ is missing in core GeoB13841-2, core GeoB13801-2 displays a gradually decreasing LSR down to $50 \mathrm{~cm} / \mathrm{kyr}$ until $7 \mathrm{cal} \mathrm{ka} \mathrm{BP.} \mathrm{Both} \mathrm{cores} \mathrm{consistently} \mathrm{show}$ low LSR of $50 \mathrm{~cm} /$ kyr during mid and late Holocene times (Fig. 4b).

Early Holocene sediment was recovered in core GeoB13841-2 as a 630-cm thick succession, which has formed over an extremely short time span of only $1.5 \mathrm{kyr}$ (11.5-10.00 cal ka BP; Fig. 5). This succession is mainly composed of sandy silts with frequently occurring $\mathrm{mm}$ - to several $\mathrm{cm}$-thick beds of silty fine sands to pure fine sands. This interval contains high abundances of biogenic carbonaceous shell fragments (mainly bivalves) with numerous intact Yoldiella bivalves (cp. Fig. 6c). Two 40-cm thick sand beds occur in the middle of this interval (at 500 and $450 \mathrm{~cm}$, ca $10.5 \mathrm{cal} \mathrm{ka} \mathrm{BP;} \mathrm{Fig.} \mathrm{5).}$

The early Holocene between 10.4 and $8.2 \mathrm{cal} \mathrm{ka} \mathrm{BP}$ is recorded in core GeoB13801-2 (Fig. 5). The lithology is again characterized by sandy silts but with frequently intercalating fine-sand layers, and high abundances of biogenic shell fragments and articulated Yoldiella specimens (950-750 cm, 10.4-9.9 cal ka BP; Fig. 5). The interval also contains a $40-\mathrm{cm}$ thick massive sand bed ( $9.6 \mathrm{cal} \mathrm{ka} \mathrm{BP})$. The transition from early to middle Holocene is characterized by a $200-\mathrm{cm}$ thick interval of massive silty sands in GeoB13801-2 (610-410 cm, 9.2-7.0 cal ka BP). This interval correlates with a succession of four $15-50-\mathrm{cm}$ thick sand beds in core GeoB13840-1 (380-190 cm, 9.3-7.0 cal ka $\mathrm{BP})$.

Homogenous sandy silts characterize the later Holocene in core GeoB13801-2 ( $<340 \mathrm{~cm},<7$ cal ka BP), similar to the homogenous fine signature found in the other two cores $(<190 \mathrm{~cm}$ in GeoB13840-1, <155 cm in GeoB13841-2). The interval in core GeoB13801-2 contains two 10-cm thick sand beds $(330$ and $260 \mathrm{~cm})$. Lithostratigraphic correlation suggests a hiatus at $7.0-4.5 \mathrm{cal} \mathrm{ka} \mathrm{BP}$ in the more proximal core GeoB13840- and at 10.0-4.5 cal ka BP in the more distal core GeoB13841-2 (Fig. 5; both located on the northern section of the terrace, Fig. 2). The top of GeoB13801-2 shows a modern age based on significantly increasing stable carbon isotope values obtained from this core, which were interpreted as the anthropogenic Suess effect (Bender et al., 2013). Both northerly cores show, in contrast, a slight coarsening trend in their late Holocene sections, possibly comparable to a subtle coarsening at $170 \mathrm{~cm}$ in core GeoB13801-2 (3.1 cal ka BP), but a subsequent fining is missing. This observation suggests that their core-tops are not modern and a radiocarbon age in core GeoB13841-2 at $34 \mathrm{~cm}$ core depth dates back to $1.78 \mathrm{cal} \mathrm{ka}$ BP (cf. Fig. 4), again suggesting that this part of the terrace got repeatedly exposed to a local bottom process either interrupting local sediment supply or, more probable, preventing supplied sediment to accumulate at a particular site on the terrace. 


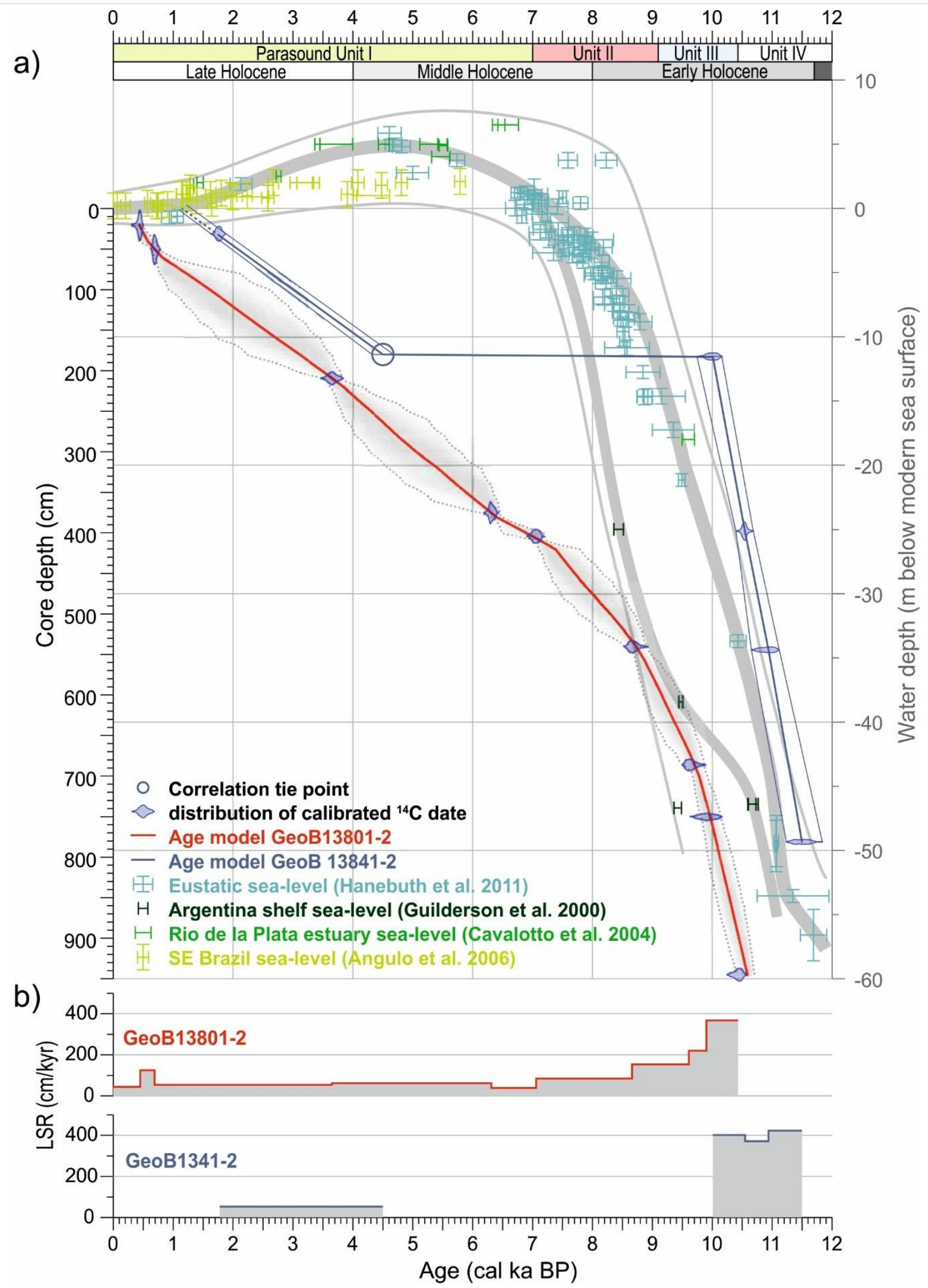

Fig. 4. (a) Depth/age models of GeoB13801-2 (red line: mean of the underlain age model obtained with Bacon in shades of grey; enveloping grey dotted lines: the model's 95\% probability interval) and GeoB13841-2 (blue line) along with Holocene relative sea-level reconstruction as a composite of regional data from Angulo et al. (2006; Southeastern Brazil); Cavallotto et al. (2004; Río de la Plata estuary) and Guilderson et al. (2000; Argentine shelf), as well as eustatic data from Hanebuth et al. (2011). All sea-level age points were recalibrated following the procedure described for the age model of the present cores; thin solid grey lines represent a simple graphic 
envelope around the sea-level data points, while thick solid grey lines represent the graphic interpolation of potential regional (Guilderson et al., 2000) and eustatic (Hanebuth et al., 2011) sea level history. Data coverage regarding the regional sea level history off Southeast South American is good after ca. $7 \mathrm{cal} \mathrm{ka} \mathrm{BP}$, but is very sparse for the Holocene period prior to $7 \mathrm{cal} \mathrm{ka} \mathrm{BP.} \mathrm{To} \mathrm{fill} \mathrm{this} \mathrm{gap} \mathrm{the} \mathrm{eustatic}$ sea-level data were added. Contrasting the middle and late Holocene, the early Holocene regional data points from the Argentine shelf diverge several meters from the eustatic data, suggesting significant regional effects on deglacial sea-level rise off Argentina e.g., due to subsidence. Albeit, a single data point from the Río de la Plata estuary at ca. $9.55 \mathrm{cal} \mathrm{ka}$ PB correlates well with the eustatic data, underlining the need for an extension of the sea level data set off Uruguay. In the following, for the early Holocene time period, the eustatic data are used as the minimum and the regional data as the maximum location of sea level below modern mean sea surface (bmss). (b) Linear sedimentation rates (LSR) for the two cores resulting from linear interpolation between the tie points shown in panel (a).

Tracing the most prominent reflectors in the PARASOUND profile, which crosses site GeoB13801, leads to an identification of four successive depositional units, of which three are recovered by the sediment core (Figs. 3b, c and 5). The lowermost Unit IV shows a relatively weak reflection and sub-parallel internal reflectors. The upper part of Unit IV is nearly transparent. Unit III is characterized by strong sub-parallel reflectors and corresponds to the predominately silty lithology with frequently occurring fine sand beds. Unit II appears almost transparent with only subtle sub-parallel reflections and correlates with the massive sand interval. The youngest Unit I shows few strong sub-parallel reflectors, which are probably caused by the isolated sand beds embedded in the silty late Holocene sedimentary facies (Fig. 5).

Radiography imaging performed on core GeoB13801-2 illustrated that several successive processes left imprints in the sedimentary record (Fig. 6). The texture is commonly characterized by $\mathrm{cm}$-sized remains of originally laminated deposits, now surrounded by a homogenized matrix (Fig. 6a).

While original bedding in the form of intercalating silty and sandy horizons remains widely preserved, the effect of syn-depositional to early post-depositional fluidization processes is evident, shown as flame-like rising structures and local sediment intrusion (Fig. 6b). At certain intervals below $720 \mathrm{~cm}$ core depth, angular sediment clasts with internally preserved lamination occur in a chaotic matrix; and double-valved bivalve specimen, certainly originally set up upright in life position, got a secondary orientation along the secondary flow direction (Fig. 6c). Shortly after these secondary structures had developed, bioturbation has further overprinted the texture at all core depths, as can be seen in Figure 6 as cloudy or spreiten (banded pattern) burrow structures.

The grain-size distribution (GSD) in core GeoB13801-2 displays a distinct terrigenous fine-sand mode at $150 \mu \mathrm{m}$ throughout the whole Holocene record (Fig. 7a). Only during the earliest Holocene (10.5-9.8 cal ka BP), the deposit is poorly sorted (lowermost spectra plots in Fig. 7a). Though still dominated by the terrigenous grain-size fraction (no significant difference between bulk and terrigenous data), a subtle finer terrigenous mode at $70-90 \mu \mathrm{m}$ is present in this interval. Also, a $10-\mu \mathrm{m}$ mode occurs in the bulk sediment distribution (middle spectra plot in Fig. 7a), indicating a biogenic contribution. This interval corresponds to the massive fine-sand interval of Unit II $(9.2-7.0 \mathrm{cal}$ ka BP; Fig. 5). After $7.0 \mathrm{cal} \mathrm{ka} \mathrm{BP,} \mathrm{the} \mathrm{biogenic} 10-\mu$ m mode coarsens towards $15-20 \mu \mathrm{m}$ and gains influence over middle and late Holocene times, which might hint to stronger primary productivity around the shelf edge.

The GSD in core GeoB13841-2 from the northern terrace section (Fig. 7b), though the record is interrupted by hiati, shows similar trends as seen for the southern core GeoB13801-2. The 150- $\mu$ m mode dominates the terrigenous fraction throughout the Holocene, and the secondary biogenous mode at $15-20 \mu \mathrm{m}$ is subordinately present in the bulk samples. Grain-size samples older than $11 \mathrm{cal}$ ka BP compare to the early Holocene samples in core GeoB13801-2, characterized by very poor sorting and a subtle terrigenous mode at $70-90 \mu \mathrm{m}$ (lowermost spectra plot in Fig. 7b).

The Holocene grain-size spectra for the outer-shelf cores (GeoB13835-2, GeoB13836-2, GeoB13837-2; Fig. 7c) are dominated by terrigenous material. The GSD of these deposits constantly shows a highly pronounced terrigenous grain-size mode at $150 \mu \mathrm{m}$. This mode shows striking similarity to the one found in the two terrace records (Fig. 7d).

The Neodymium isotopic analysis on the terrigenous fraction of core GeoB13801-2 provided $\varepsilon N d$ values between -1.9 and -0.1 (Fig. 8). Following the fundamental studies by Mahiques et al. (2008) and Mantovanelli et al. (2018), which have defined the $\varepsilon N d$ signatures for the major rock source areas along the SESA continental margin, these values illustrate a singular and constant supply of sediment to TO throughout the Holocene from the southern Argentine/Patagonian source province ( $\varepsilon N d-4$ to 0 ; Fig. 8 ). These values are also consistent with the $\varepsilon \mathrm{Nd}$ signature of the lowstand system on the outer shelf $(\varepsilon N d-1.4$ to -0.5$)$ as well as of the overlying transgressive-to-highstand sediment cover $(\varepsilon N d-0.5$ to -0.4 for the past 16.5 cal ka BP; Lantzsch et al., 2014).

\section{Discussion}

\subsection{Deposition on the terrace: shelf sediment export dynamics versus the effect of bottom flow}

The SESA continental margin sedimentation is largely controlled by a strong bottom-current regime (HernándezMolina et al., 2009, 2016; Violante et al., 2010; Preu et al., 2012). To unravel the forces controlling deposition on the 
terrace, it is required to first differentiate between the influence of a contour-parallel bottom flow versus a direct local sediment supply through suspension settling or gravitational flows across or right below the shelf edge.

The upper depocenter on the northern PARASOUND profile (Fig. 9a) shows a slightly convex shape, with a subtle moat separating the depocenter from the steep shelf-edge slope, and an aggradational-progradational internal geometry (Fig. 2). These observations point to a certain influence of
RESEARCH PAPER slope-parallel bottom currents on lateral sediment dispersal, generating an offshore-directed bottom transport component.

The responsible current is probably guided and experiences velocity acceleration by the steep shelf-edge slope, leading to intense erosion there, and deposition on the seaside of the main current action. The outer of the two depocenters might receive this lateral sediment but a bottom current might limit the upward growth not above the surrounding basement here.

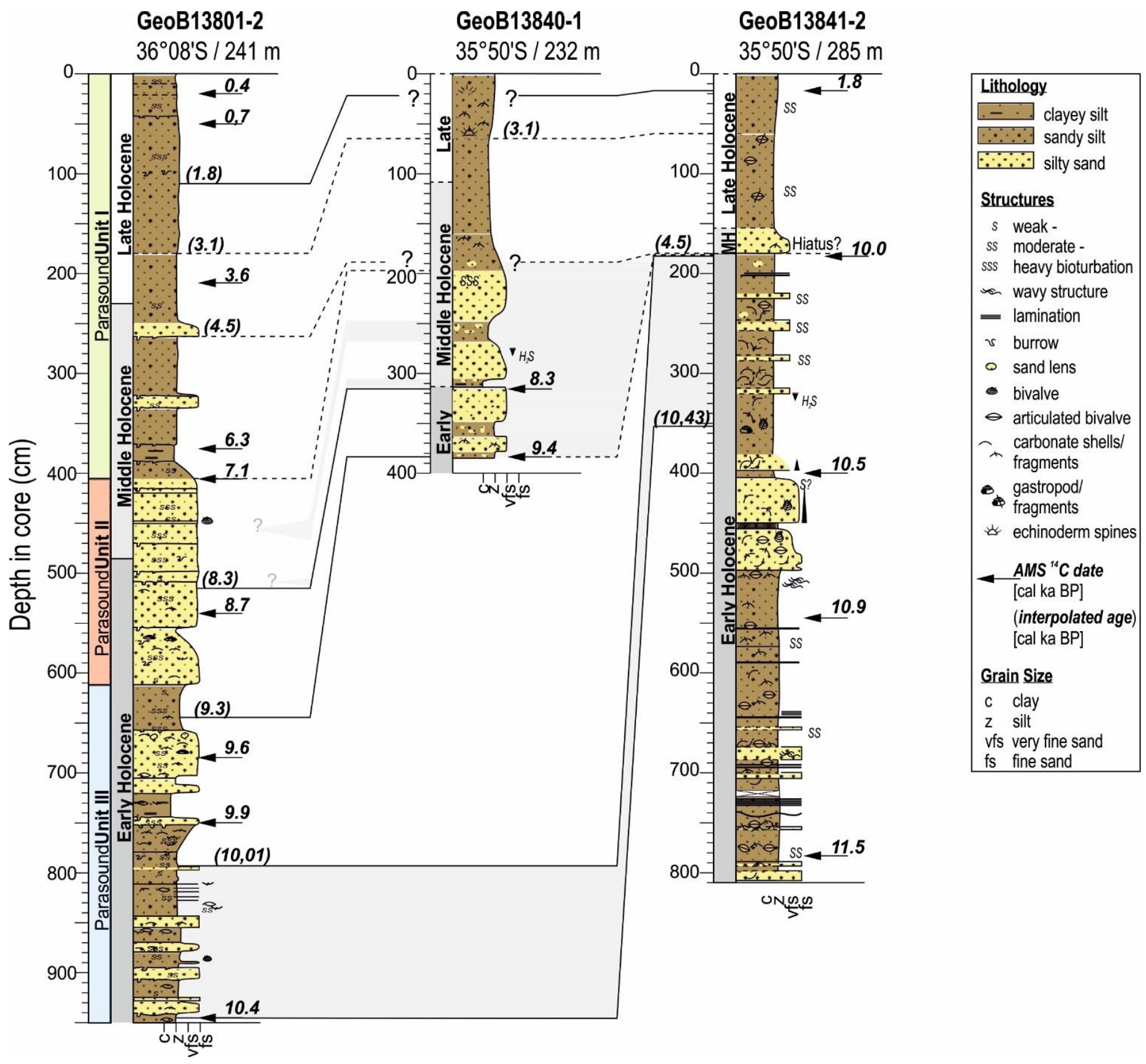

Fig. 5. Chronostratigraphic (solid lines) and lithostratigraphic (dashed lines) correlation between the three uppermost slope terrace cores GeoB13801-2, GeoB13840-1 and GeoB13841-2. Radiocarbon dates (in bold) are given to the right of the core columns at the respective sampling depths, interpolated ages (in parentheses) were obtained from the age model of core GeoB13801-2 (Fig. 4a). All ages are in calibrated ka BP (cal ka BP). To the left of GeoB13801-2 the respective PARASOUND units inferred from Fig. 3c are given. 
Whilst the northern profile shows two depocenters isolated from each other (Fig. 2), the southern profile illustrates continuous sediment coverage across the whole terrace, with a thinning trend at its outer edge (Figs. 3, 9a). The overall draping sediment layering clearly illustrates a vertical settling mechanism. The pinching out at the seaward edge hints to a subordinate slope-parallel bottom-current control at the edge of the terrace as it is the case for the northern section where a bottom current leads to local seafloor blanking.

A comparable sand-rich slope-plastered depocenter, interpreted as contourite body is described for the upper
RESEARCH PAPER slope (200-600 m water depth) from the Campos Basin (off Southeastern Brazil at $22-23^{\circ} \mathrm{S}$ ) as the result of shelf-edge sediment spill-over processes interacting with the western boundary Brazil Current (Viana and Faugéres, 1998; Viana, 2002).

In that case, the conditioning factors for sand accumulation on the upper slope were proposed to be a) a convex plus bay-shaped upper-slope morphology, b) sandy sediments available at the shelf edge, c) off-shelf transport of sands driven by strong currents at the shelf edge, and d) the presence of the strong Brazil Current on the upper slope (Viana and Faugéres, 1998).
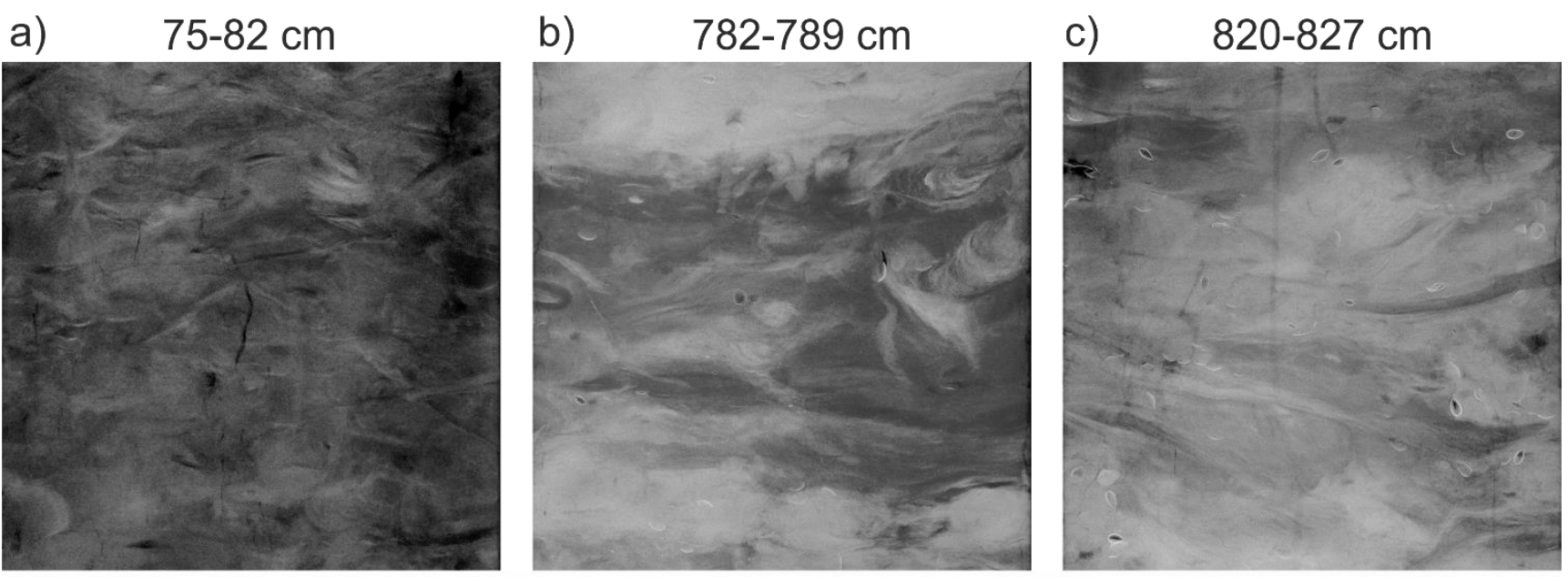

Fig. 6. Radiographies at selected depths of core GeoB13801-2. (a) Chaotic fabric with laminated mud flakes swimming in a bioturbated matrix. (b) Fluidization texture overprinted by a weak later invading burrow activity. (c) Chaotic fabric with angular clasts supported by a matrix which was later bioturbated. Note the secondary disorientation of the double-valves shells.

While Points b-d likewise apply to our study area, an explicit overall along-slope convex seafloor topography is not given. Instead, the upper slope is intersected by canyon structures, which occur at a lateral spacing of about $60 \mathrm{~km}$ (Franco-Fraguas et al., 2014; Hernández-Molina et al., 2016). These structures, each about $15 \mathrm{~km}$ wide, probably lead to an intense turbulent interaction with the slope-parallel bottom flow (Viana and Faugéres, 1998; Preu et al., 2012; Voigt et al., 2013) of the southward-directed BC.

Since the modern STSF is located exactly above the studied terrace section (Fig. 1), this mechanism would explain why the deposits in the northern area of the terrace (Fig. 2) appear more controlled by a bottom current (BC) than in the southern area (Fig. 3). This observation is in consistency with a coarser sediment cover found at the uppermost continental slope to the north of the STSF, compared to sediment south of it (Franco-Fraguas et al., 2014).

The distinction of current-controlled (i.e., contouritic) from vertically settled (i.e., hemipelagic) and downslope (i.e., gravity-driven) sedimentary processes can also be made on the basis of the sedimentological data. The fact that the deposits all over the terrace are mainly composed of the same distinct fine-sand population $(150 \mu \mathrm{m})$ as found on the outer shelf (Fig. 7d) indicates that the terrace is primarily built-up by direct off-shelf sediment export, and not by sediments transported over wider distances by bottom currents.

This interpretation is corroborated by the terrigenous $\varepsilon N d$ signature from both the terrace and the outer-shelf deposits, which indicates a persistent southern material source (Fig. 8), whilst deposits from geological older successions on the shelf show partly a Río de la Plata province signature (Lantzsch et al., 2014). Thus, it can be excluded that the STSF went significantly south of the study area during Holocene times since a cross-shelf sediment export of Río de la Plata derived material can be excluded.

The intercalation of coarse-silty with fine-sandy deposition, found in the sediment cores, does not offer a clear picture in terms of a differentiation between stormrelated, gravity-driven and pulse-like contouritic sediment dynamics. Some of the sandy horizons seem to show a defined base and a certain fining-upward trend, which may hint to turbiditic transport events (sensu Stow and Mayall, 2000) rather than to a waxing-waning change in bottomcurrent intensity (sensu Stow et al., 2002). 


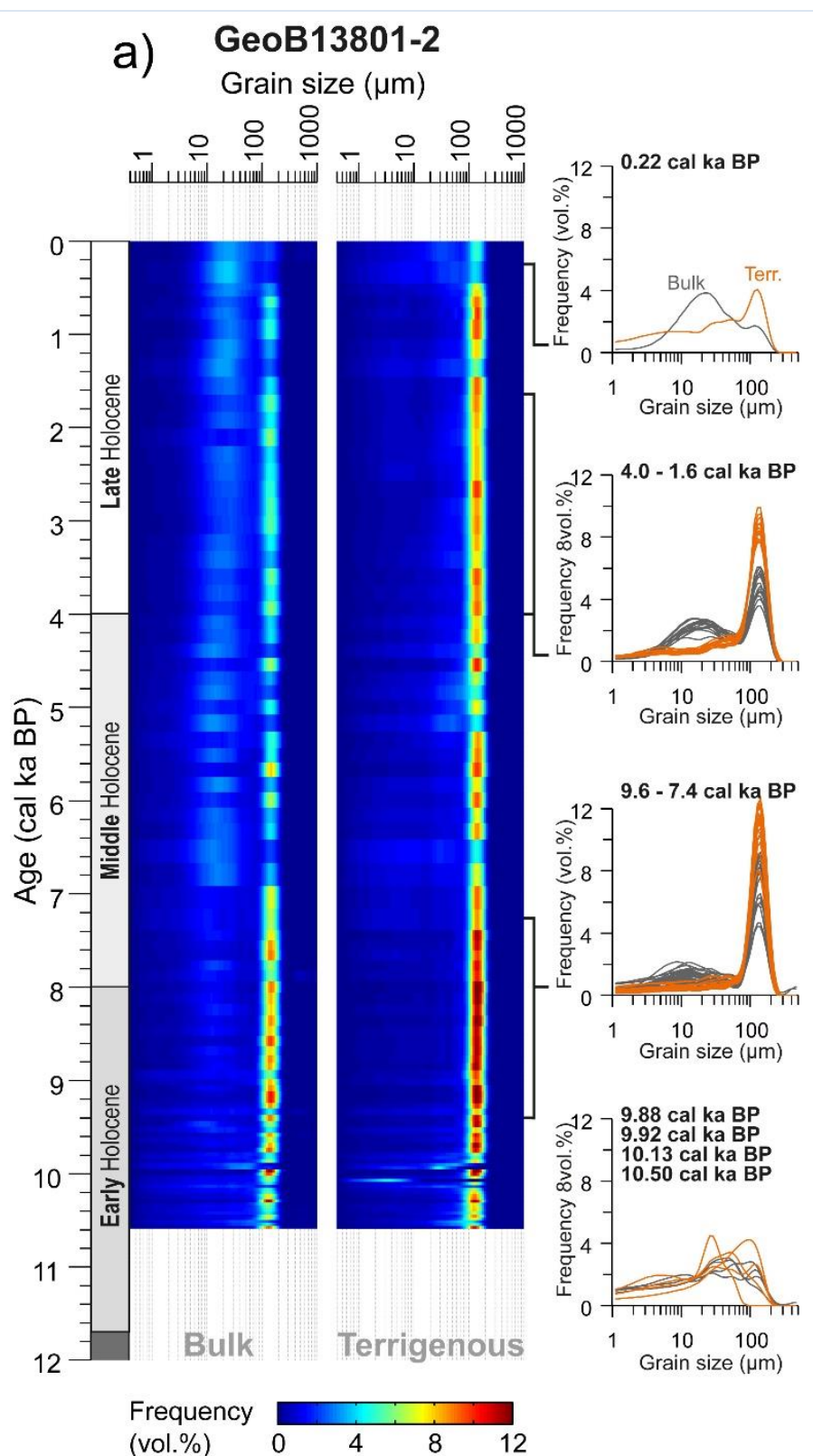

c)

Holocene outer-shelf fine-sand drape

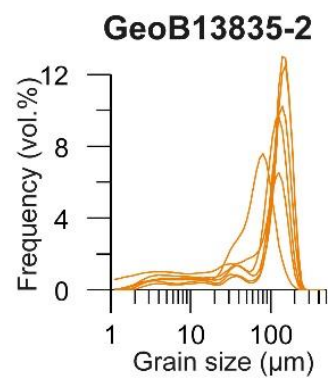

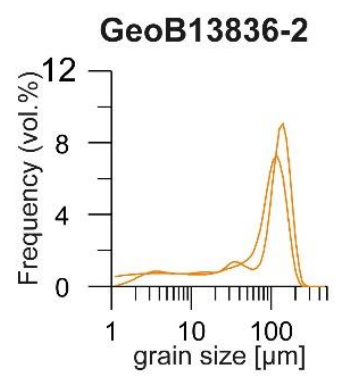

\section{b) GeoB13841-2 \\ Grain size $(\mu \mathrm{m})$}

RESEARCH PAPER

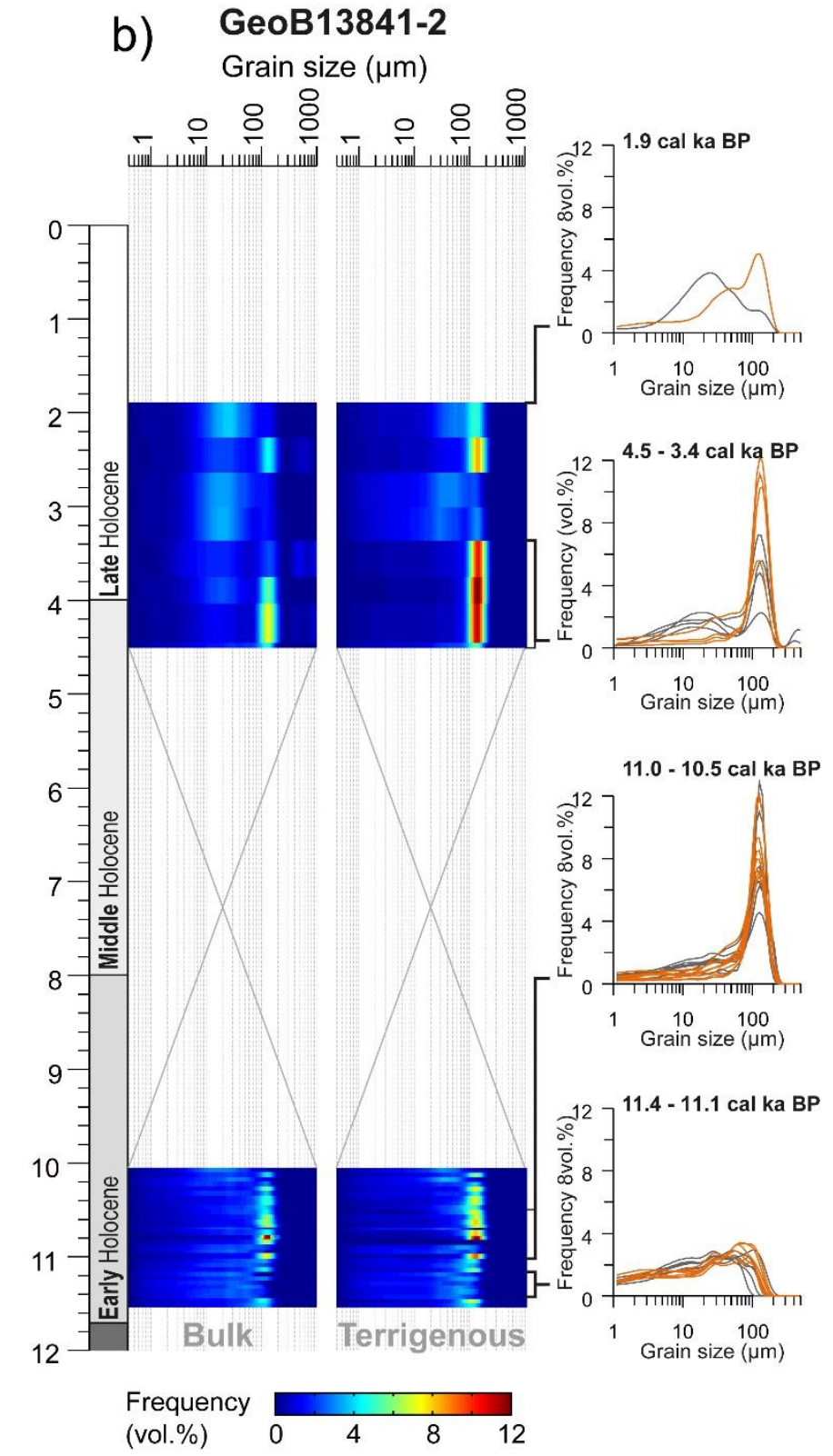

d) Mean terrigenous grain size
Outer shelf $(n=12)$
GeoB13801-2 $(n=96)$

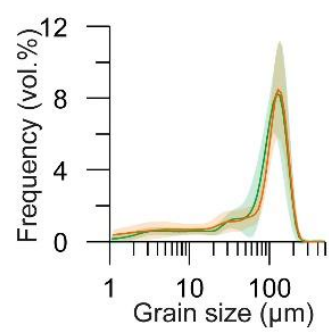

Fig. 7. Bulk and terrigenous down-core grain size distributions of cores GeoB13801-2 (a) and GeoB13841-2 (b). A prominent 150 $\mu$ m mode is dominating the bulk as well as the terrigenous grain size spectra of both cores throughout the Holocene. (c) Terrigenous grain size spectra of the outer shelf sand drape samples (cf. Figs. 1b, 2a). (d) A comparison of the mean grain size distributions (GSD) of all outer shelf samples (green, $n=12$ ) shown in (c) with the mean terrigenous GSD of GeoB13801-2 (orange, $n=96$ ) identifies the outer shelf sand drape as a potential direct source for the $150 \mu \mathrm{m}$ sand mode. Shaded areas demark the respective 1-sigma envelope. 


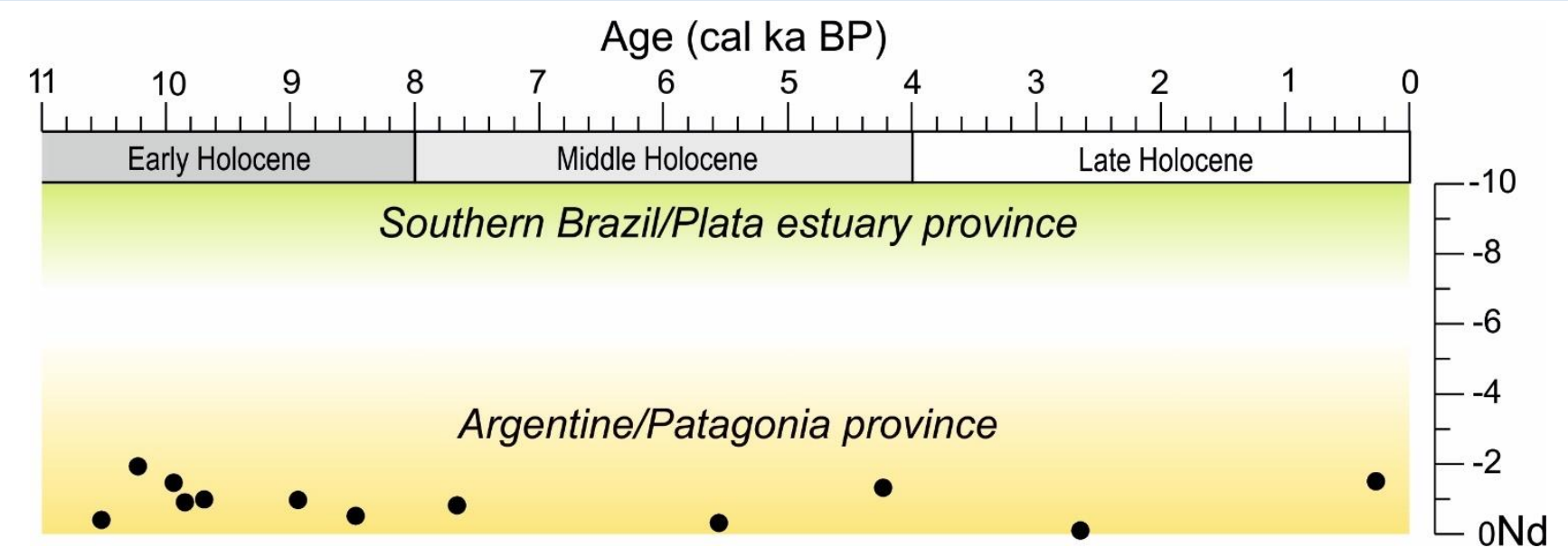

Fig. 8. $\varepsilon \mathrm{Nd}$ values in core GeoB13801-2 plotting inside the range of the Argentine/ Patagonian source province (province signatures from Mahiques et al., 2008).

The radiographs do not support an interpretation of deposition as a result from gravity-driven turbidity flows. The original laminated or bedded texture of the deposit, rather, hints to common changes in the intensity of local sediment supply. The intercalation of finer- and coarsergrained deposition on the terrace might, thus, be explained by the alternation of two modes of sediment export from the shelf: i) A lower-energy, more continuous supply driven by the main shelf bottom currents, which are related to the shelf branch of the Malvinas Current (Gwilliam, 1996; Piola et al., 2008) and to the STSF (Bender et al., 2013); ii) Storm events, which provide episodic spill-outs of sandy suspension clouds, which, in turn, settle rapidly down with a subtle degree of sediment sorting (fining-upward sequences).

The fact that some deposits show no intact sedimentsettling texture but clasts and flakes supported by a matrix can be counted as evidence that these sediments were subordinately fluidized or creeping downslope shortly after deposition. Lateral contour-parallel bottom flows or vertical settling from a suspension cloud would not be able to mix clasts - as big as a few cm - into a fine sandy matrix, and downslope transport in the form of turbidity currents would lead to graded deposition

A similar texture was found in contouritic terrace deposits off northwestern Argentina where well-sorted fine sand forms 10's of meters thick successions (Krastel et al., 2012; Preu et al., 2013). Thus, it can be assumed - in the absence of cohesive material and when one well-sorted grain-size population dominates - that sediment mobilization in the form of internal grain movement and internal liquification flows has led to the disintegration of the original fabric. How locally limited this mobilization is, has been demonstrated by the basically undisturbed paleoceanographic record established for this core (Bender et al., 2013). The internal fluidization might result either (i) from rapid vertical accumulation of a large amount of sand in the course of an event, or from (ii) incoming internal waves (Pomar et al 2012; Zhang et al., 2016). Both mechanisms may lead a to pressure change in the pore water and, thus, to sudden dewatering of the shallow underlying sediment (Fig. 6b).

As a result, it can be stated that the formation of turbidity currents transporting shelf sands towards the deeper slope off Uruguay and building up prominent turbidite successions (as illustrated by the numerous sediment cores stored at Lamont-Doherty Earth Observatory Deep-Sea Sample Repository; geomapapp.org) seems to start not at the shelf edge. Rather, these turbidity currents can only form below the terrace level, i.e. at water depths greater than 340 $\mathrm{m}$. This conclusion, in turn, means that the sediment is turning into a turbidity current not instantaneously after it has been spilled over the shelf edge raining down onto the terrace. Thus, the terrace acts as a temporary sediment collector.

\subsection{Holocene shelf sediment mobilization bistory}

Accepting that the deposition on Terrace TO is fed via direct shelf sediment supply, it is straightforward to consider the deglacial sea-level rise and the associated drowning and deepening of the continental shelf as a major player. The correlation of sedimentation rates and lithologic units with the successive stages in deglacial-to-early-Holocene sea-level rise supports this hypothesis (Fig. 4).

Early Holocene high sedimentation rates of up to $400 \mathrm{~cm} / \mathrm{kyr}$ reflect intense mobilization of shallow outershelf material in the run of the early Holocene transgression across the mid-shelf region (Fig. 4b). For the northern terrace section, rapid deposition has experienced a drastic reduction around $10 \mathrm{cal} \mathrm{ka} \mathrm{BP}$ on the outer part, lasting until $8.5 \mathrm{cal} \mathrm{ka} \mathrm{BP}$ on the inner part (Fig. 5). In the south, sedimentation was continuously active over the Holocene 


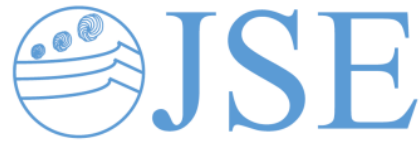

RESEARCH PAPER

but at drastically reduced rates after $8.5 \mathrm{cal} \mathrm{ka} \mathrm{BP} \mathrm{(Fig.} \mathrm{4b).}$ Around 10 to $8.5 \mathrm{cal} \mathrm{ka} \mathrm{BP}$, a critical threshold in the oceanographic system, thus, appears to have been crossed. This change is reflected by the 5.5-kyr lasting hiatus in core GeoB13841-2 and a decreasing LSR from 150 to $80 \mathrm{~cm} / \mathrm{ka}$ in core GeoB13801-2 (Fig. 4b). Following the concept of transgressive reworking dynamics, sea level was arriving at 45-25 m below modern sea level around $8.5 \mathrm{cal} \mathrm{ka} \mathrm{BP} \mathrm{(Fig.}$ 4a; Guilderson et al., 2000; Violante et al., 2010; Hanebuth et al., 2011). The newly established sedimentation pattern on the inundated mid-to-inner shelf have, thus, led to reduced sand dispersal towards the outer shelf, lowering sediment accumulation on the outer terrace.

At the same time ( $\geq 9.4-7.2 \mathrm{cal} \mathrm{ka} \mathrm{BP})$, the STSF significantly shifted from a position around the study area to the north due to a strengthening of the Westerly Winds, as indicated by paleoceanographic proxies (Bender et al., 2013). Thus, an overall decrease in sediment accumulation could also be related to the latitudinal departure of the STSF as major off-shelf material conveyer supplying sediments to the outer shelf and over the shelf edge. Wainer et al. (2014) have described progressively drier climatic conditions over SESA for the time interval around 10 to $8.2 \mathrm{ka}$, with wetter conditions returning afterwards. This change coincides with the pronounced sandy lithology at 9.2-7.0 cal ka BP (Fig. 4 and 5: GeoB13801-2 and GeoB 13840-1). It might, thus, be that a climatic aridification has led to either reduced fluvial runoff due to reduced precipitation rates or stronger wind events driving shelf sediment remobilization, or a combination of both.

The vertical density front between SAW and SACW can also be found in this geographic location (de Mello et al., 2014; Franco-Fraguas et al., 2014), which adds another layer of complexity to the hydrodynamic geometry. The occurrence of a biogenic mode after 7.0 cal ka BP (Fig. 7) reflects an intensifying primary productivity around the shelf edge. This observation supports the idea that the whole front system has stabilized further northward around $7.2 \mathrm{cal} \mathrm{ka} \mathrm{BP}$ (Bender et al., 2013). Today, the vertical boundary between SAW and SACW is located right at the study site and its density boundary sharply separates the high productivity SAW waters $\left(>1,000 \mathrm{gC} / \mathrm{m}^{2} \mathrm{yr}^{-1}\right)$ from the lower productivity SACW waters $\left(<500 \mathrm{gC} / \mathrm{m}^{2} \mathrm{yr}^{-1}\right.$; de Mello et al., 2014).

The subsequent approach of modern sea-level conditions invoked a re-organization in distribution of fine material on the shelf and export off the shelf (Fig. 4a). This change is reflected by the appearance of a $20-\mu \mathrm{m}$ mode, i.e. a silty lithology after $7 \mathrm{cal} \mathrm{ka} \mathrm{BP} \mathrm{(Figs.} 5$ and 7a). Around this time, the modern frequency of warm El Niño Southern Oscillation (ENSO) events initiated (Moy et al., 2002). Under modern conditions, warm ENSO events result in enhanced precipitation over SESA, leading to increasing river discharge (Garreaud et al., 2009). Due to the coincidence of an appearing silty sub-fraction on the terrace with the onset of the modern ENSO frequency as well as the modern sea-level conditions, having led to full flooding of the Río de la Plata estuary (Lantzsch et al., 2014), we suggest a fluvial origin for the $20-\mu \mathrm{m}$ mode population.

The reinstating sedimentation in the northern area of the terrace around $4.5 \mathrm{cal} \mathrm{ka} \mathrm{BP}$ coincides with the maximum regional sea-level highstand which was $2-5 \mathrm{~m}$ above the modern mean surface (Cavallotto et al., 2004; Angulo et al., 2006; García-Rodríguez, 2012; Fig. 4a). In addition, proxybased studies have indicated that modern humidity conditions have established over SESA after ca. 4 cal ka BP (Chiessi et al., 2010; Cruz et al., 2005; Razik et al., 2013). Moreover, the $\mathrm{BC}$ has experienced periodical changes (ca. $730 \mathrm{yr}$ ) in strength throughout the Late Holocene (Chiessi et al., 2014; Mantovanelli et al., 2018). This strengthened (weakened) BC intensity would lead to a southward (northward) shift of the position of the STSF placing it farther from (closer to) our core sites, and the sedimentary succession would reflect the long-term high-energy-end of these conditions.

Whereas core GeoB13801-2 has a recent core top, cores GeoB13840-1 and GeoB13841-2 are lacking the recent-most 1.2 cal ka BP. Exactly at the same time, a 10-m thick mud depocenter has initiated to form inside the Río de la Plata paleo-valley (Lantzsch et al., 2014; Perez et al., 2017; Mourelle et al; 2018). Their study has linked the initiation of this depocenter on the Uruguayan inner shelf to changes in the Río de la Plata drainage basin as well as a southward shift of the STSF. Though the terrace record does not allow for identifying what has exactly caused the changes at 4.5 and $1.2 \mathrm{cal} \mathrm{ka} \mathrm{BP}$, it is obvious that the entire system from coast to uppermost slope was affected by these general environmental changes. The paleoceanographic record extracted from GeoB13801-2 does not show a late Holocene southward STSF shift prior some 200 years ago and this subrecent shift has been linked to an anthropogenic influence on the climate system (Bender et al., 2013; Marrero et al., 2015).

\subsection{Oceanographic implications}

The upper $200 \mathrm{~m}$ of the water column in the study area experience large seasonal temperature changes, suggesting competitive dominances of STSW vs. SASW (on the shelf) and SACW vs. SAW (on the upper slope), and thus reversals in current directions (Fig. 9b). The water masses below $220 \mathrm{~m}$ water depth are probably only little affected by these alternating conditions. Terrace TO is located inside the transition zone between modern SACW/SAW and AAIW, which is mainly characterized by a salinity gradient from 34.2 to 34.9 psu (Fig. 9b; Piola and Matano, 2001). Being situated inside a mixing zone, often referred to as 'water mass boundary', could explain the existence of the terrace as well as the shape of the depocenters since these zones are the preferred highways for internal waves. 


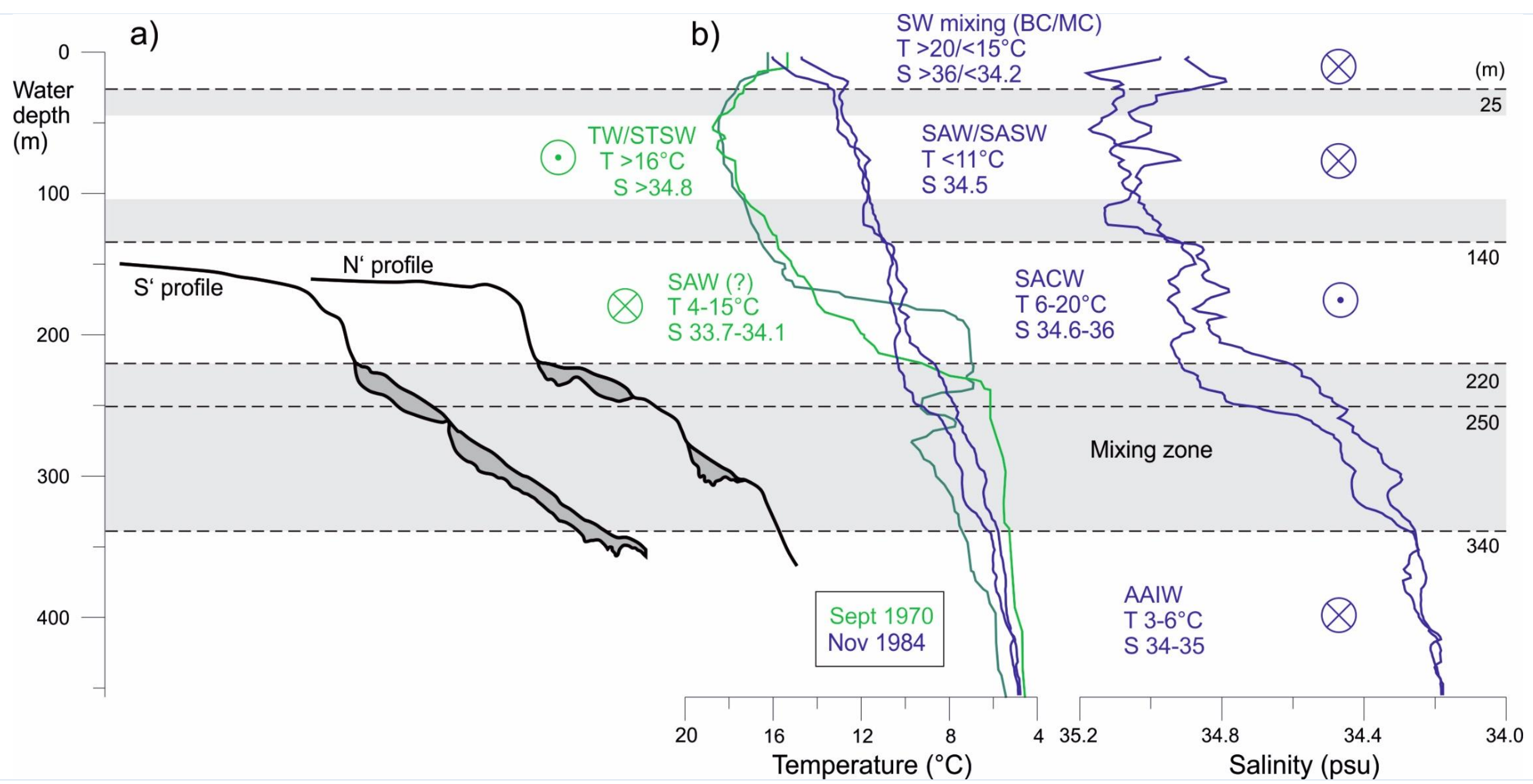

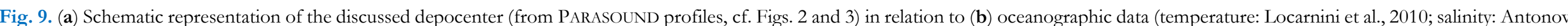

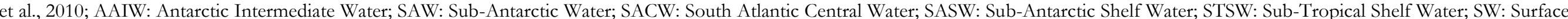
Water; TW: Tropical Water). Water masses, boundaries (dashed lines; grey bars: transition zones) and flow directions are indicated according to Piola and Matano, 2001. 


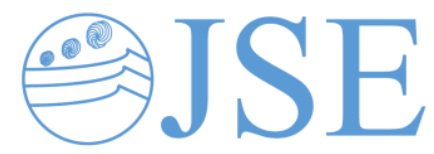

RESEARCH PAPER
It was recently suggested that the turbulent energy at water-mass boundaries (through internal waves) provide an effective mechanism for vertically confined deposition and, thus, for long-term formation of terrace structures at continental margins (Preu et al., 2013; Rebesco et al., 2014). Arriving wave trains that travel along such water-mass boundaries would lead to intense sediment mobilization (e.g., Pomar et al., 2012). The idea of Preu et al. (2013) is based on the existence of distinct water-mass interfaces due to strong contrasts in water-mass properties in concert with a persistent contouritic bottom flow, which leads to lasting deposition directly underneath the water-mass boundary. Temperature and salinity profiles in the study area show, however, that the boundary between SACW and AAIW at T0 displays a $120-\mathrm{m}$ thick transition zone at $220-340 \mathrm{~m}$ water depth, rather than a sharp contact (Antonov et al., 2010; Locarnini et al., 2010). According to a novel conceptual model by Hanebuth et al. (2015), such transition zones offers an effective medium for laterally migrating hydrographic fronts triggered by subtle density differences. These fronts, in concert with associated $\mathrm{km}$-scale eddies, supposedly represent a widespread phenomenon, easily able to mobilize and redeposit fine sands over a rough topography (Hanebuth et al., 2015).

The fact that the terrace TO hosts thick deposits hints to little lateral sediment transport inside the transition zone. It further suggests strong current-seabed interaction and erosion by the deeper $\mathrm{BC}$ (transporting $\mathrm{SACW}$ ) flow core on the steep shelf-edge slope (Fig. 9). Nevertheless, hydrographic front-related pulses should be expected to occur episodically within the transition zone as resulting from internal waves between the southward flowing SACW, transported by the $\mathrm{BC}$, and the northward flowing upper AAIW, transported by the MC. Those density-driven hydrodynamic front pulses, however, do not need to leave explicit horizons neither in the lithological succession nor in the grain-size signature on the terrace (Hanebuth et al., 2015).

The remarkable thickness of Holocene deposits on TO with maximum LSRs of $400 \mathrm{~cm} / \mathrm{kyr}$ for the early Holocene and minimum LSRs of $50 \mathrm{~cm} / \mathrm{kyr}$ for the late Holocene, in comparison with the overall thickness of terrace deposits of up to $15 \mathrm{~m}$, indicates that most of the glacial-lowstand and deglacial aged strata are largely condensed or even missing. This observation evidences that either i) the shelf has supplied much less material during lower sea level configurations; or ii) large amounts of sediment have bypassed the terrace at that time; or iii) deposits have later been eroded by significantly enhanced slope bottom flows. The outer shelf was continuously inundated by several 10's of meters during glacial sea-level lowstand (Violante et al., 2010; Guilderson et al., 2000; Lantzsch et al., 2014), and sea level started rising already around 19 cal ka BP (Clark et al., 2004; Chiessi et al., 2008; Hanebuth et al., 2009). It is, thus, difficult to explain why the volume of sediment available should have been drastically reduced prior to the Holocene, and why the transport mode should have changed from vertical settling to gravity-driving bypassing.

As a plausible alternative, a strengthening and deepening of the southward flowing BC core during glacial/deglacial times would offer an explanation why sediment accumulation was so limited until early Holocene times. Mahiques et al. (2007) and Nagai et al. (2010) suggested an offshore displacement of the $\mathrm{BC}$ core during glacial times as consequence of the lowered sea level, which has drastically reduced shelf width and shelf water depth. A strengthened and, thus, deepened $\mathrm{BC}$ core (composed of SACW) above the uppermost continental slope would then have exposed the terrace to enhanced bottom-flow velocity, and would, thus, lead to low or no deposition on the terrace. Also, the transport of $\mathrm{BC}$ intermediate waters seems to have generally been intensifying during the last glacial (Clauzet et al., 2007). Though not much is known about the transition time between high glacial and the Holocene interval, it seems reasonable to assume that due to the $\mathrm{BC}$ current strength SACW was a bit deeper and its flow has enhanced during glacial-deglacial times compared to the later Holocene. Chiessi et al. (2014) have demonstrated for the Holocene that during times of decreasing Atlantic meridional overturning circulation (AMOC) the $\mathrm{BC}$ has been strengthening. Taking this into account, periods of major AMOC weakening during LGM and deglacial at least until $15 \mathrm{ka}$ (Carlson et al., 2008) would have promoted a strengthening of the $\mathrm{BC}$, which would also have contributed to a hampering of sediment accumulation on the terraces off Uruguay.

\section{Conclusion}

A $20-\mathrm{km}$ long and $5.5-\mathrm{km}$ wide uppermost slope terrace off Uruguay at 220-340 m water depth (Terrace TO) hosts a 15-m thick internally stratified sediment depocenter, which provides an exceptional geological archive for reconstructing the shelf sediment export history. A distinct, spatially and temporally persisting $150-\mu \mathrm{m}$ (fine sand) grain-size population, identical to that found on the outer shelf, together with a terrigenous $\varepsilon \mathrm{Nd}$ signature similar to that found in outer-shelf deposits, indicate that the terrace strata built up mainly through direct, local off-shelf sediment export. The slightly convex shape of the sediment depocenter and a subordinate alternation between coarsesilty and fine-sandy layers are probably related to recurrent spill-outs of shelf sediment during storm events, and to a slight variation in slope-parallel bottom current velocity on the terrace itself. Generally, the morpho-sedimentary architecture along the Southeast South American continental margin is controlled by strong bottom currents. Bottomcurrent related sediment transport appears, however, to play only a subtle role in the built-up of this terrace depocenter.

The stratigraphic geometry and the sedimentary record of the terrace suggest that sediment supplied from the shelf 


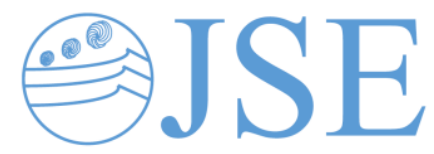

RESEARCH PAPER

in the form of suspension clouds vertically raining down onto the terrace as the main sediment transport process. The beds of turbidity currents transporting shelf sands into the deep ocean and forming turbidite successions at the lower slope have been frequently observed in the study area. These coarse-grained, gravity-driven sediment suspension bottom currents thus, seem to initiate at water depths below the terrace. This process of sudden post-depositional sediment mobilization requires, in turn, an interim sediment storageand-supply mechanism, which is provided by the terrace as a temporary sink for the shelf sands. A new sediment mobilization at the terrace leading to a bulk sand export over the edge of the terrace may be triggered during incoming internal wave events since these waves of large vertical amplitudes preferably travel along the density gradients of horizontal transitions zones between two water masses.

A terrace-wide hiatus and drastically decreasing linear sedimentation rates around 10.0-8.5 cal ka BP together with a pronounced sandy lithology on the terrace reflects the effect of the deglacial sea-level rise on the mid-shelf region. Flooding of the mid- to inner shelf has created a new sedimentary regime on the shelf and has eventually reduced the availability of fine (silty) sediments for off-shelf export.

After $7 \mathrm{cal} \mathrm{ka} \mathrm{BP}$, the arrival of a new terrigenous $20-\mu \mathrm{m}$ grain size mode composed of chemically weak bound aggregates is interpreted as being of fluvial origin. Increased availability and re-organization of fine material distribution on the shelf, due to the approach of the modern sea-level position as well as the onset of the modern El Niño Southern Oscillation mode controlling the wind system, has delivered this silty sediment to the terrace. Whereas in the southern part of the terrace deposition continued uninterruptedly, reinstating and again ceasing deposition in its northern part after ca. 4 cal ka BP happened synchronously with the establishment of humidity over Southeast South America in late Holocene times.

Cessation of deposition in the northern part of the terrace at $1.2 \mathrm{cal} \mathrm{ka} \mathrm{BP}$ has occurred contemporaneously with the initiation of a 10-m thick mud depocenter inside the Río de la Plata paleo-valley on the innermost shelf off the Uruguayan coast. This initiation was suggested to have been linked to climatic changes in the Río de la Plata drainage basin as well as to a southward shift of the Sub-Tropical Shelf Front. The shelf-wide effect of this change to the sedimentary system, i.e., from inner-shelf (Río de la Plata paleo-valley) to upper-most slope (northern part of Terrace TO), at ca. $1.2 \mathrm{cal}$ ka BP suggests a general regional climatic, i.e., atmospheric forcing mechanism driving the shallowwater hydrodynamics.

Temperature and salinity profiles from the study area show that, under modern oceanographic conditions, Terrace T0 is located inside a $120-\mathrm{m}$ thick transition zone between South Atlantic Central Water/Sub-Antarctic Water and Antarctic Intermediate Water. The density gradient in such a transition zone offers an effective medium for laterally migrating oceanic density-driven pulses. Such density fronts are able to distribute fine sands over rough topographies. Remarkably thick early Holocene deposits on Terrace TO hint to comparably calm conditions inside this transition zone, suggesting the Sub-Tropical Shelf Front, having been located further south than it is the case today, as a main sediment export agent.

\section{Acknowledgements}

This study was funded through the DFG Graduate College "Proxies in Earth History (EUROPROX)" and DFGResearch Center / Cluster of Excellence "The Ocean in the Earth System" (MARUM). We thank Benedict Preu for processing of the PARASOUND data. We further thank Anna Lipke, whose B.Sc. thesis initially demonstrated the scientific potential of the uppermost-slope terrace deposits, and Cristiano Chiessi for making the Neodymium analyses at the Universidade de São Paulo, Geosciences Department (São Paulo, Brazil) possible. The data reported in this paper are archived in PANGAEA (www.pangaea.de).

\section{References}

Angulo, R.J., Lessa, G.C., de Souza, M.C., 2006. A critical review of mid- to late-Holocene sea-level fluctuations on the eastern Brazilian coastline. Quaternary Science Reviews 25, 486-506. https://doi.org/10.1016/j.quascirev.2005.03.008

Antonov, J.I., Seidov, D., Boyer, T.P., Locarnini, R.A., Mishonov, A.V., Garcia, H.E., Baranova, O.K., Zweng, M.M., Johnson, D.R., 2010. World Ocean Atlas 2009, Vol. 2: Salinity. U.S. Government Printing Office, Washington, D.C., 184 pp. https://repository.library.noaa.gov/view/noaa/1259

Bender, V.B., Hanebuth, T.J.J., Chiessi, C.M., 2013. Holocene shifts of the Subtropical Shelf Front off southeastern South America controlled by high and low latitude atmospheric forcings. Paleoceanography 28, 481-490. https://doi.org/10.1002/palo.20044

Blaauw, M., Christen, J.A., 2011. Flexible paleoclimate age-depth models using an autoregressive gamma process. Bayesian Analysis 6, 457-474. https://doi.org/10.1214/11-BA618

Campos, E.J.D., Mulkherjee, S., Piola, A.R., de Carvalho, F.M.S. 2008. A note on a mineralogical analysis of the sediments associated with the Plata River and Patos Lagoon outflows. Continental Shelf Research 28, 1687-1691. https://doi.org/10.1016/j.csr.2008.03.014

Carlson, A.E., Oppo, D.W., Came, R.E., LeGrande, A.N., Keigwin, L.D., Curry, W.B., 2008. Subtropical Atlantic salinity variability and Atlantic meridional circulation during the last deglaciation. Geology 36, 991-994. https://doi.org/10.1130/G25080A.1

Cavallotto, J.L., Violante, R.A., Parker, G., 2004. Sea-level (Argentina). Quaternary International 114, 155-165. https://doi.org/10.1016/S1040-6182(03)00050-8

Chiessi, C.M., Mulitza, S., Groeneveld, J., Silva, J.B., Campos, M.C., Gurgel, M.H.C., 2014. Variability of the Brazil Current during the late Holocene. fluctuations during the last 8600 years in the de la Plata river 


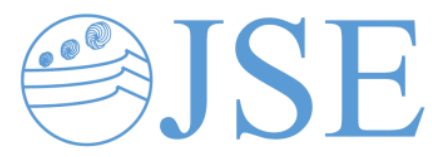

RESEARCH PAPER

Palaeogeography, Palaeoclimatology, Palaeoecology 415, 28-36. https://doi.org/10.1016/j.palaeo.2013.12.005

Chiessi, C.M., Mulitza, S., Pätzold, J., Wefer, G., 2010. How different proxies record precipitation variability over southeastern South America. IOP Conference Series: Earth and Environmental Science 9, 012007. https://doi.org/10.1088/1755-1315/9/1/012007

Chiessi, C.M., Mulitza, S., Paul, A., Pätzold, J., Groeneveld, J., Wefer, G., 2008. South Atlantic in-terocean exchange as the trigger for the Bølling warm event. Geology 36 (12), 919-922. https://doi.org/10.1130/G24979A.1

Clark, P.U., McCabe, A.M., Mix, A.C., Weaver, A.J., 2004. Rapid rise of sea level 19,000 years ago and its global implications. Science 304, 1141-1144. https://doi.org/10.1126/science.1094449

Clauzet, G., Wainer, I., Lazar, A., Brady, E., Otto-Bliesner, B., 2007. A numerical study of the South Atlantic circulation at the Last Glacial Maximum. Palaeogeography Palaeoclimatology Palaeoecology 253, 509-528. https://doi.org/10.1016/j.palaeo.2007.06.018

Cruz, F.W., Burns, S.J., Karmann, I., Sharp, W.D., Vuille, M., Cardoso, A.O., Ferrari, J.A., Dias, P.L.S., Viana, O., 2005. Insolation-driven changes in atmospheric circulation over the past 116,000 years in subtropical Brazil. Nature 434, 63-66. https://doi.org/10.1038/nature03365

de Mello, C., Burone, L., Ortega, L., Franco-Fraguas, P., Lahuerta, N., Mahiques, M., Marin, Y., 2014. Benthic foraminiferal distributions on the Uruguayan continental margin (Southwestern Atlantic) and controlling environmental factors. Continental Shelf Research 91, 120-133. https://doi.org/10.1016/j.csr.2014.08.006

Folk, R.L., 1968. The petrology of sedimentary rocks. Hemphill Publishing Company, Austin, Texas, 170 pp.

Franco-Fraguas, P., Burone, L., Mahiques, M.M., Ortega, L., Urien, C., Munoz, A., Lopez, G., Marin, Y., Carranza, A., Lahuerta, N., de Mello, C., 2014. Hydrodynamic and geomorphological controls on surface sedimentation at the Subtropical Shelf Front/Brazil-Malvinas Confluence transition off Uruguay (Southwestern Atlantic Continental Margin). Marine Geology 349, 24-36. https://doi.org/10.1016/j.margeo.2013.12.010

García-Rodríguez, F., 2012. South America: Holocene coastal lagoons. In: Encyclopedia of Lakes and Reservoirs. Geography, Geology, Hydrology and Paleolimnology (Eds L. Brengtsson, R. Herschy and R. Fairbridge), Springer, pp. 723734. https://doi.org/10.1007/978-1-4020-4410-6_164

Garreaud, R.D., Vuille, M., Compagnucci, R., Marengo, J., 2009. Present-day South American climate. Palaeogeography Palaeoclimatology Palaeoecology 281, 180-195. https://doi.org/10.1016/j.palaeo.2007.10.032

Guilderson, T.P., Burckle, L., Hemming, S., Peltier, W.R., 2000. Late Pleistocene sea level variations derived from the Argentine Shelf. Geochemistry Geophysics Geosystems 1, 1055. https://doi.org/10.1029/2000GC000098

Gwilliam, C.S., 1996. Modelling the global ocean circulation on the T3D. In: Parallel Computational Fluid Dynamics (Eds A. Ecer, J. Periaux, N. Satdfuka and S. Taylor), Elsevier, Amsterdam, pp. 33-40. https://doi.org/10.1016/B978-044482322$9 / 50058-\mathrm{X}$
Hamilton, P.J., O'Nions, R.K., Bridgwater, D., Nutman, A., 1983. Sm-Nd studies of Archaean metasediments and metavolcanics from West Greenland and their implications for the Earth's early history. Earth and Planetary Science Letters 62, 263-272. https://doi.org/10.1016/0012-821X(83)90089-4

Hanebuth, T.J.J., Zhang, W., Hofmann, A.L., Löwemark, L.A., Schwenk, T., 2015. Oceanic density fronts steering bottom-current induced sedimentation deduced from a $50 \mathrm{ka}$ contourite drift record and numerical modelling. Quaternary Science Reviews 112, 207-225. https://doi.org/10.1016/j.quascirev.2015.01.027

Hanebuth, T.J.J., Voris, H.K., Yokoyama, Y., Saito, Y., Okuno, J., 2011. Formation and fate of sedimentary depocentres on Southeast Asia's Sunda Shelf over the past sea-level cycle and biogeographic implications. Earth-Science Reviews 104, 92110. https://doi.org/10.1016/j.earscirev.2010.09.006

Hanebuth, T.J.J., Stattegger, K., Bojanowski, A., 2009. Termination of the Last Glacial Maximum sea-level lowstand: The Sunda-Shelf data revisited. Global and Planetary Change 66, 76-84. https://doi.org/10.1016/j.gloplacha.2008.03.011

Hernández-Molina, F.J., Paterlini, M., Violante, R., Marshall, P., de Isasi, M., Somoza, L., Rebesco, M., 2009. Contourite depositional system on the Argentine Slope: An exceptional record of the influence of Antarctic water masses. Geology 37, 507-510. https://doi.org/10.1130/G25578A.1

Hernández-Molina, F.J., Soto, M., Piola, A.R., Tomasini, J., Preu, B., Thompson, P., Badalini, G., Creaser, A., Violante, R.A., Morales, E., Paterlini, M., 2016. A contourite depositional system along the Uruguayan continental margin: sedimentary, oceanographic and paleoceanographic implications. Marine Geology 378, 333-349. https://doi.org/10.1016/j.margeo.2015.10.008

Isupova, M.V., Mikhailov, V.N., 2018. Long-Term Variations of Water Runoff and Suspended Sediment Yield in the Parana and Uruguay Rivers. Water resources 45(6), 846-860. https://doi.org/10.1134/S0097807818060088

Krastel, S., Wefer, G., and cruise participants, 2012. Report and preliminary results of RV METEOR Cruise M78/3. Sediment transport off Uruguay and Argentina: From the shelf to the deep sea. 19.05.2009 - 06.07.2009, Montevideo (Uruguay) Montevideo (Uruguay). Berichte, Fachbereich Geowissenschaften, Universität Bremen, No. 285, 79 pp. ISSN: 0931-0800

Lantzsch, H., Hanebuth, T.J.J., Chiessi, C.M., Schwenk, T., Violante, R.A., 2014. The high-supply, current-dominated continental margin of southeastern South America during the late Quaternary. Quaternary Research 81, 339-354. https://doi.org/10.1016/j.yqres.2014.01.003

Locarnini, R.A., Mishonov, A.V., Antonov, J.I., Boyer, T.P., Garcia, H.E., Baranova, O.K., Zweng, M.M., Johnson, D.R., 2010. World Ocean Atlas 2009, Volume 1: Temperature. U.S. Government Printing Office, Washington, D.C., 184 pp. https://doi.org/10.7289/V55X26VD

Mahiques, M.M., Tassinari, C.C.G., Marcolini, S., Violante, R.A., Figueira, R.C.L., da Silveira, I.C.A., Burone, L., Sousa, S.H.M., 2008. Nd and $\mathrm{Pb}$ isotope signatures on the Southeastern South American upper margin: Implications for sediment transport and source rocks. Marine Geology 250, 51-63. https://doi.org/10.1016/j.margeo.2007.11.007 
Mahiques, M.M., Fukumoto, M.M., Silveira, I.C.A., Figueira, R.C.L., Bicego, M.C., Lourenco, R.A., Sousa, S.H.M., 2007. Sedimentary changes on the Southeastern Brazilian upper slope during the last 35,000 years. Anais da Academia Brasileira de Ciências 79, 171-181. https://doi.org/10.1590/S000137652007000100018

Mantovanelli, S.S., Tassinari, C., Mahiques, M.M., Jovane, L. and Bongiolo, E., 2018. Characterization of $\mathrm{Nd}$ radiogenic isotope signatures in sediments from the Southwestern Atlantic Margin. Frontiers in Earth Science 6, 74 https://doi.org/10.3389/feart.2018.00074

Marrero, A., Tudurí, A., Pérez, L., Cuña, C, Muniz, P., Figueira, R.C.L., Mahiques, M.M., Pittauerova, D., Hanebuth, T.J.J., García-Rodríguez, F., 2015. Historical changes in terrigenous river supply from the Rio de la Plata basin to the inner shelf of Uruguay (in Spanish). Latin American Journal of Sedimentology and Basin Analysis 21 (2), 166-179. hdl.handle.net/11336/45880

Martins, L.R., Martins, I.R., Martins, R.R., 2005. Utilização de Testemunhador Livre na Região dos Poços de Lama. Gravel 3, 1-8. ISSN: $1678-5975$

Martins, L.R., Martins, I.R., Urien, C.M., 2003. Aspectos sedimentares da plataforma continental na área de Influência do Rio de La Plata. Gravel 1, 68-80. ISSN: 1678-5975

Matano, R.P., Palma, E.D., Piola, A.R., 2010. The influence of the Brazil and Malvinas Currents on the Southwestern Atlantic Shelf circulation. Ocean Science 6, 983-995. ISSN: 1812-0784

Miller, M.C., McCave, I.N., Komar, P.D., 1977. Threshold of sediment motion under unidirectional currents. Sedimentology 24, 507-527. https://doi.org/10.1111/j.13653091.1977.tb00136.x

Möller, O.O., Piola, A.R., Freitas, A.C., Campos, E.J.D., 2008. The effects of river discharge and seasonal winds on the shelf off southeastern South America. Continental Shelf Research 28, 1607-1624. https://doi.org/10.1016/j.csr.2008.03.012

Mourelle, D., Pérez, L., Hanebuth, T.J.J., Lantzsch, H., GarcíaRodríguez, F., 2018. Oceanographic changes over the past millennium reconstructed from a palynological record off Uruguay. Journal of Sedimentary Environments 3 (4), 234-252. https://doi.org/10.12957/jse.2018.39141

Moy, C.M., Seltzer, G.O., Rodbell, D.T., Anderson, D.M., 2002. Variability of El Niño/Southern Oscillation activity at millennial timescales during the Holocene epoch. Nature 420, 162-165. https://doi.org/10.1038/nature01194

Nagai, R.H., Sousa, S.H.M., Lourenço, R.A., Bícego, M.C., Mahiques, M.M., 2010. Paleoproductivity changes during the Late Quaternary in the Southeastern Brazilian upper continental margin of the Southwestern Atlantic. Brazilian Journal of Oceanography 58, 31-41. https://doi.org/10.1590/S1679-87592010000500004

Parker, G., Paterlini, C.M., Violante, R.A., Costa, I.P., Marcolini, S., Cavallotto, J.L., 2005. Geologá submarina: Plataforma continental frente a Mar del Plata, Provincia de Buenos Aires. XVI Congreso Geológico Argentino, la Plata. Actas III, 817824. ISSN: $1669-7316$

Perez, L., García-Rodríguez, F., Hanebuth, T.J.J., 2016. Variability in terrigenous sediment supply offshore of the Rio de la Plata (Uruguay) recording the continental climatic history over the past 1200 years. Climate of the Past 12, 623-634. https://doi.org/10.5194/cp-12-623-2016
RESEARCH PAPER

Peterson, R.G., Stramma, L. 1991. Upper-level circulation in the South Atlantic Ocean. Progress In Oceanography 26, 1-73. https://doi.org/10.1016/0079-6611(91)90006-8

Piola, A.R., Möller, O.O., Guerrero, R.A., Campos, E.J.D., 2008. Variability of the subtropical shelf front off eastern South America: Winter 2003 and summer 2004. Continental Shelf Research 28, 1639-1648. https://doi.org/org/10.1016/j.csr.2008.03.013

Piola, A.R., Matano, R.P., Palma, E.D., Möller, O.O., Campos, E.J.D., 2005. The influence of the Plata River discharge on the western South Atlantic shelf. Geophysical Research Letters 32, 4. https://doi.org/10.1029/2004GL021638

Piola, A.R., Matano, R.P., 2001. Brazil and Falkland (Malvinas) Currents. In: Ocean Currents: A Derivative of the Encyclopedia of Ocean Sciences (Eds J.H. Steele, S.A. Thorpe and K.K. Turekian). Academic Press, Elsevier Ltd., London, Burlington, San Diego, pp. 35-43. ISBN: 978-0-08-96486-7

Piola, A.R., Campos, E.J.D., Möller, O.O., Charo, M., Martinez, C., 2000. Subtropical Shelf Front off eastern South America. Journal of Geophysical Research - Oceans 105, 6565-6578. https://doi.org/10.1029/1999JC000300

Pomar, L., Morsilli, M., Hallock, P., Badenas, B., 2012. Internal waves, an under-explored source of turbulence events in the sedimentary record. Earth-Science Reviews 111, 56-81. https://doi.org/10.1016/j.earscirev.2011.12.005

Preu, B., Hernández-Molina, F.J., Violante, R., Piola, A.R., Paterlini, C.M., Schwenk, T., Voigt, I., Krastel, S., Spiess, V., 2013. Morphosedimentary and hydrographic features of the northern Argentine margin: The interplay between erosive, depositional and gravitational processes and its conceptual implications. Deep Sea Research Part I: Oceanographic Research Papers 75, 157-174. https://doi.org/10.1016/j.dsr.2012.12.013

Preu, B., Schwenk, T., Hernández-Molina, F.J., Violante, R., Paterlini, M., Krastel, S., Tomasini, J., Spiess, V., 2012. Sedimentary growth pattern on the northern Argentine slope: The impact of North Atlantic Deep Water on southern hemisphere slope architecture. Marine Geology 329, 113-125. https://doi.org/10.1016/j.margeo.2012.09.009

Razik, S., Chiessi, C.M., Romero, O.E., von Dobeneck, T., 2013, Interaction of the South American Monsoon System and the Southern Westerly Wind Belt during the last $14 \mathrm{kyr}$. Palaeogeography Palaeoclimatology Palaeoecology 374, 28-40. https://doi.org/10.1016/j.palaeo.2012.12.022

Reading, H.G., Richards, M., 1994. Turbidite systems in deepwater basin margins classified by grain-size and feeder system. AAPG Bulletin-American Association of Petroleum Geologists 78, 792-822.

Rebesco, M., Hernández-Molina, F.J., Van Rooij, D., Wåhlin, A., 2014. Contourites and associated sediments controlled by deep-water circulation processes: State-of-the-art and future considerations. Marine Geology 352, 111-154. https://doi.org/10.1016/j.margeo.2014.03.011

Reimer, P.J., Baillie, M.G.L., et al., 2009. Intcal09 and Marine09 radiocarbon age calibration curves, 0-50,000 years cal BP. Radiocarbon 51, 1111-1150. https://doi.org/10.1017/S0033822200034202

Sato, K., Tassinari, C.C.G., Kawashita, K., Petronilho, L., 1995. O Método Geocronológico Sm-Nd No IGc-USP e Suas 


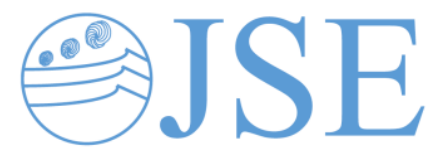

RESEARCH PAPER

Aplicações. Anais da Academia Brasileira de Ciências 67, $313-$ 336. ISSN: 0001-3765

Stow, D.A.V., Faugères, J.-C., Howe, J.A., Pudsey, C.J., Viana, A.R., 2002. Bottom currents, contourites and deep-sea sediment drifts: current state-of-the-art. Geological Society, London, Memoirs 22, 7-20. https://doi.org/10.1144/GSL.MEM.2002.022.01.02

Stow, D.A.V., Mayall, M., 2000. Deep-water sedimentary systems: New models for the 21st century. Marine and Petroleum Geology 17, 125-135. https://doi.org/10.1016/S0264-8172(99)00064-1

Stramma, L., England, M., 1999. On the water masses and mean circulation of the South Atlantic Ocean. Journal of Geophysical Research - Oceans 104 20863-20883. https://doi.org/org/10.1029/1999JC900139

Swift, D.J.P., 1974. Continental shelf sedimentation. In: The Geology of Continental Margins (Eds C.A. Burk and C.L. Drake), Springer, New York, pp. 117-135. https://doi.org/org/10.1007/978-3-662-01141-6_10

Urien, C.M., Ewing, M., 1974, Recent sediments and environments of Southern Brazil, Uruguay, Buenos Aires, and Rio Negro continental shelf. In: The Geology of Continental Margins (Eds C.A. Burk and C.L. Drake), Springer, Berlin, Heidelberg, New York, pp. 157-177. https://doi.org/org/10.1007/978-3-662-01141-6_12

Viana, A.R., 2002. Seismic expression of shallow- to deep-water contourites along the south-eastern Brazilian margin. Marine Geophysical Researches 22, 509-521. https://doi.org/org/10.1023/A:1016307918182

Viana, A.R., Faugéres, J.-C., 1998. Upper slope sand deposits: the example of Campos Basin, a latest Pleistocene-Holocene record of the interaction between alongslope and downslope currents. In: Geological Processes on Continental Margins: Sedimentation, Mass-Wasting and Stability (Eds M.S. Stoker, D. Evans and A. Cramp), Geological Society, London, Special Publications 129, 287-316. https://doi.org/org/10.1144/GSL.SP.1998.129.01.18

Violante, R.A., Paterlini, C.M., Costa, I.P., Hernández-Molina, F.J., Segovia, L.M., Cavallotto, J.L., Marcolini, S., Bozzano, G., Laprida, C., García Chapori, N., Bickert, T., Spieß, V., 2010. Sismoestratigrafia y evolución geomorfológica del talud continental adyacente al litoral del este bonaerense, Argentina. Latin American Journal of Sedimentology and Basin Analysis 17, 33-62. ISSN: 1669-7316

Voigt, I., Henrich, R., Preu, B.M., Piola, A.R., Hanebuth, T.J.J., Schwenk, T., Chiessi, C.M., 2013. A submarine canyon as a climate archive - Interaction of the Antarctic Intermediate Water with the Mar del Plata Canyon (Southwest Atlantic). Marine Geology 341, 46-57. https://doi.org/org/10.1016/j.margeo.2013.05.002

Wainer, I., Prado, L.F., Khodri, M., Otto-Bliesner, B., 2014. Reconstruction of the South Atlantic Subtropical Dipole index for the past 12,000 years from surface temperature proxy. Scientific Reports 4, Artn 5291. ISSN: 2045-2322

Zhang, W., Cui, Y., Santos, A.I., Hanebuth, T.J., 2016. Stormdriven bottom sediment transport on a high-energy narrow shelf (NW Iberia) and development of mud depocenters. Journal of Geophysical Research: Oceans 121(8), 5751-5772. https://doi.org/10.1002/2015JC011526 